\title{
Ways of dying: multiple pathways to apoptosis
}

\author{
Jerry M. Adams ${ }^{1}$ \\ The Walter and Eliza Hall Institute of Medical Research, Melbourne, Victoria 3050, Australia
}

In order to eliminate cells that are redundant, damaged, or infected, metazoan organisms have evolved the cell suicide mechanism termed apoptosis (Kerr et al. 1972). This genetic program is vital for normal development, for maintenance of tissue homeostasis, and for an effective immune system. Not surprisingly therefore, its disturbance is implicated in numerous pathological conditions, ranging from degenerative disorders to autoimmunity and cancer (Cory and Adams 2002; Cory et al. 2003).

The cell's death throes are choreographed by a set of previously dormant proteases, the caspases, which cleave several hundred cellular substrates (Thornberry and Lazebnik 1998). Two principal pathways to caspase activation have been recognized. One is triggered by engagement of so called "death receptors" on the cell surface (Strasser et al. 2000; Ashkenazi 2002). The other, of more ancient origin, is provoked by various forms of stress, including inadequate cytokine support and diverse types of intracellular damage. During stress, the cell's decision on whether to invoke the suicide program- "to be or not to be"-rests primarily with the Bcl-2 family. Its interacting opposing members integrate developmental cues with the signals received from other cells and assess intracellular damage to determine whether to throw the caspase execution switch /Gross et al. 1999; Cory and Adams 2002; Cory et al. 2003).

Early in stress-induced apoptosis of vertebrate cells, the outer membrane of the mitochondria is permeabilized, releasing cytochrome $\mathrm{c}$ and other death-promoting proteins (Newmeyer and Ferguson-Miller 2003). Because Bcl-2 can prevent this change, it has been widely assumed that commitment to all forms of stress-induced apoptosis, that is, all those regulated by the Bcl-2 family, requires this step to initiate all relevant caspase activation, and hence that Bcl-2 and its anti-apoptotic relatives function as guardians of mitochondrial integrity (Green and Reed 1998; Gross et al. 1999; Wang 2001).

That viewpoint is challenged by recent findings. It will be argued here that in stress-induced apoptosis, as in death receptor signaling (Strasser et al. 2000; Ashkenazi 2002), caspases can be activated upstream or indepen-

1E-MAIL adams@wehi.edu.au; FAX 61-3-9347-0852.

Article and publication are at http://www.genesdev.org/cgi/doi/10.1101/ gad.1126903. dently of mitochondria, and hence that the mitochondrial breach may often simply deliver the coup de grace to a cell already on the path to death. A related theme is that the Bcl-2 cohort must man checkpoints at several sites in the cell. Finally, the vexed unresolved issue of how the opposing factions of the Bcl-2 family govern caspase activation is addressed.

\section{The demolition machinery}

Caspases are cysteine proteases that cleave after certain aspartate residues (for review, see Thornberry and Lazebnik 1998; Shi 2002). The dozen or so in each mammal (Table 1) are expressed in most cell types, but to preclude unwarranted cell death, each is maintained as a zymogen. Before the "executioner" caspases (caspase-3, caspase-6, and caspase-7) can attack their cellular substrates, their zymogens must be proteolytically cleaved, typically by "initiator" caspases such as caspase- 8 and caspase-9. Unlike the executioners, each initiator caspase has a long pro-domain, and activation is triggered by dimerization of the zymogen on a dedicated adaptor or scaffold protein (Shi 2002; Boatright et al. 2003).

The death receptor pathway activates caspase-8 - and also caspase-10 in humans-via the adaptor protein FADD (Fas-âssociated death domain; Table 1). Ligandinduced aggregation of members of the tumor-necrosis factor (TNF) receptor family such as CD95 (Fas; Strasser et al. 2000; Ashkenazi 2002) attracts FADD, which recruits procaspase-8 (or procaspase-10) molecules through homologous death effector domains (DEDs). The proximity of the zymogens promotes their dimerization and subsequent autocatalysis (Boatright et al. 2003).

The stress pathway instead typically activates caspase-9 via the scaffold protein Apaf-1 (apoptotic protease activating factor), which is related to the nematode CED-4 and Drosophila Dark (for review, see Wang 2001; Shi 2002). A conformational change in Apaf-1, induced by cytochrome $\mathrm{c}$ from damaged mitochondria, allows it to recruit procaspase-9 via their homologous caspase recruitment domains (CARDs) and to oligomerize into a heptameric scaffold (Acehan et al. 2002). In the resulting giant ( 1 megadalton) "apoptosome", caspase-9 is activated primarily by allosteric change and dimerization rather than cleavage (Rodriguez and Lazebnik 1999; 
Table 1. Mammalian initiator and executioner caspases

\begin{tabular}{|c|c|c|c|c|}
\hline Human & Mouse & Pro-domain & Activators & Established or proposed function \\
\hline \multicolumn{5}{|l|}{ Initiators } \\
\hline casp 8 & casp 8 & DED & FADD & Death receptor signaling, cell proliferation \\
\hline casp 10 & none & DED & FADD & Death receptor signaling \\
\hline casp 9 & casp 9 & CARD & Apaf-1/cyt c & casp $3 / 7$ activation after mitochondrial stress \\
\hline casp 1 & casp 1 & CARD & Ipaf, ASC, inflammasome & IL-1 $1 \beta /$ IL-18 maturation, apoptosis \\
\hline $\operatorname{casp} 5^{\mathrm{a}}$ & $\operatorname{casp} 11^{\mathrm{a}}$ & CARD & inflammasome & IL-1 $\beta /$ IL-18 maturation, LPS stress \\
\hline $\begin{array}{l}\operatorname{casp} 4^{\mathrm{a}} \\
(\operatorname{casp} 12)^{\mathrm{a}}\end{array}$ & $\operatorname{casp} 12^{\mathrm{a}}$ & CARD & TRAF-2, calpain & ER stress \\
\hline casp 2 & casp 2 & CARD & DEFCAP, RAIDD & Premitochondrial stress \\
\hline \multicolumn{5}{|l|}{ Executioners } \\
\hline casp 3 & casp 3 & short & casp 9,8, others? & Cleavage of most apoptotic substrates \\
\hline casp 7 & casp 7 & short & casp 9,8, others? & Cleavage of most apoptotic substrates \\
\hline casp 6 & casp 6 & short & casp 3,7 & Lamin cleavage \\
\hline
\end{tabular}

${ }^{a}$ Due to recent gene duplications, there is some uncertainty as to which of these genes are orthologs in human and mice. A cluster of genes for casp1-casp5-casp4-(casp12) resides on human chromosome 11q22.3, but the last seems to have acquired inactivating mutations (Fischer et al. 2002). The syngeneic mouse cluster is casp1-casp11 casp12. Although casp4 could be the human homolog of mouse casp 12, its nucleotide sequence is more similar to casp11 (68\%) than casp12 (57\%).

Boatright et al. 2003). The apoptosome then processes caspase-3 and caspase-7, which initiate robust proteolysis and free a dedicated DNase (CAD/DFF40) that dices the chromatin (Enari et al. 1998). Although all stressinduced apoptosis has been attributed to caspase-9 activation, it will be argued below that other initiator caspases often participate, but first the protein family that governs the stress pathways will be sketched.

\section{The Bcl-2 family of apoptotic regulators}

As reviewed recently (Gross et al. 1999; Cory and Adams 2002; Cory et al. 2003), the 20 Bcl-2 family members in mammals fall into at least three interacting groups (Fig. 1). All share at least one of four relatively conserved Bcl-2 Homology (BH) domains. Bcl-2 and four relatives (Bcl- $\mathrm{x}_{\mathrm{L}}, \mathrm{Bcl}-\mathrm{w}, \mathrm{A} 1$, and $\left.\mathrm{Mcl}-1\right)$ promote cell survival, as do the several homologs encoded by viruses (Cuconati and White 2002). Two structurally distinct factions of cellular relatives instead elicit cell death. The "multi-BH domain" Bax, Bak, and Bok share three domains (BH1, $\mathrm{BH} 2$, and $\mathrm{BH}$ ) with Bcl-2 and, judging by Bax, also have a similar 3D structure, namely a globular bundle of $\alpha$-helices with a hydrophobic surface groove (Fesik 2000; Suzuki et al. 2000). In contrast, the eight or more diverse BH3-only proteins, such as Bim, Bad, and Bid, share only the short $\mathrm{BH} 3$ interaction domain, which is necessary and probably sufficient for their killing action. This amphipathic $\alpha$-helix of $\sim 16$ residues binds to the hydrophobic surface groove of pro-survival relatives (Sattler et al. 1997; Liu et al. 2003). Both pro-apoptotic factions seem to be required for launching apoptosis: the damage-sensing BH3-only proteins primarily antagonize the Bcl-2like proteins (Huang and Strasser 2000), whereas either Bax or Bak is essential downstream, probably in organelle perturbation (Lindsten et al. 2000; Cheng et al. 2001; Wei et al. 2001).

The association of Bcl-2 family members with organ- elles is important to their function. Bcl-2 is found on the cytoplasmic face of the outer mitochondrial membrane, endoplasmic reticulum (ER), and nuclear envelope, and its relatives either reside on one or more of these membranes or congregate there during apoptosis (Hsu et al.

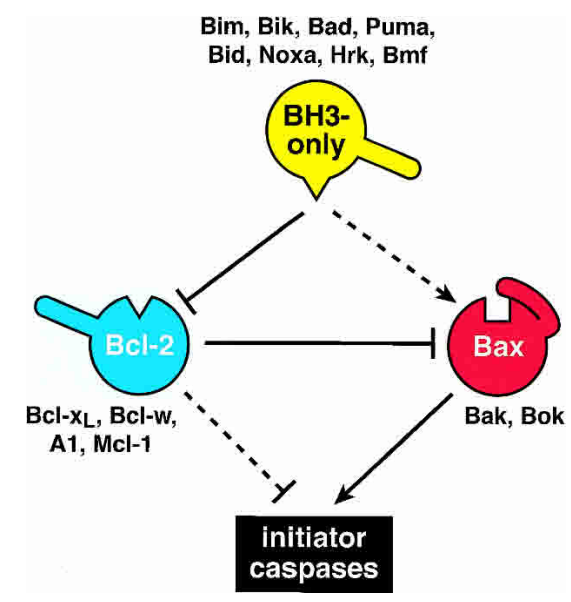

Figure 1. The three major mammalian factions of the Bcl-2 family. The BH3-only proteins (yellow) are essential initiators of apoptosis that primarily antagonize their pro-survival relatives (blue), whereas either Bax or Bak (red) is required downstream of Bcl-2. The notch on Bcl-2 represents the hydrophobic groove to which a $\mathrm{BH} 3$-only protein attaches, and Bax has a somewhat similar groove, into which its $\mathrm{C}$ terminus can curl. Whether certain BH3-only proteins, such as Bid, can also activate Bax/Bak by direct binding is uncertain (see Fig. 4). Bax and Bak probably indirectly promote caspase activation via membrane perturbation, but whether Bcl-2 inhibits caspase activation entirely by preventing Bax/Bak activation is unclear. The pro-survival homologs of Bcl-2 encoded by viruses (e.g., E1B 19K, EBV BHRF1) are reviewed elsewhere (Cuconati and White 2002). Other cellular proteins related to Bcl-2 (Boo/Diva, Bcl-G, Bcl-B, Bfk, Bcl-Rambo, BNIP3, BNIP3L) are not shown, because their function is not well understood; Blk (not shown) is now considered the mouse ortholog of human Bik. 
1997; Kaufmann et al. 2003). The hydrophobic C-terminal domain on most family members helps target them to organelle membranes (Kaufmann et al. 2003), but their avidity for membranes is surprisingly variable. Whereas Bcl-2 is an integral membrane protein even in healthy cells (Janiak et al. 1994), Mcl-1 is cytosolic (Nijhawan et al. 2003), and much of Bcl-w and Bcl- $x_{\mathrm{L}}$, like Bax, becomes tightly membrane-associated only after an allosteric change imposed by cytotoxic signals (Hsu et al. 1997; Wilson-Annan et al. 2003). Pertinently, like Bax (Suzuki et al. 2000), the C-terminal tail of Bcl-w normally occupies the hydrophobic groove to which $\mathrm{BH} 3$ ligands bind (Hinds et al. 2003). Engagement by Bcl-w of a $\mathrm{BH} 3$-only protein (or $\mathrm{BH} 3$ peptide) displaces the tail and allows membrane association (Wilson-Annan et al. 2003). The varied membrane affinities of the pro-survival proteins may be indicative of somewhat different functions.

Bax and Bak appear to permeabilize the outer mitochondrial membrane, allowing efflux of apoptogenic proteins (see below; Gross et al. 1999; Martinou and Green 2001; Newmeyer and Ferguson-Miller 2003). Whereas Bax is predominantly a cytosolic monomer in healthy cells, during apoptosis it undergoes conformational changes at both termini, translocates to the outer mitochondrial membrane, and oligomerizes (Hsu et al. 1997; Antonsson et al. 2001; Mikhailov et al. 2001; Nechushtan et al. 2001). Bak is present in that membrane even in healthy cells but also changes conformation and forms larger aggregates (Griffiths et al. 1999; Wei et al. 2000; Antonsson et al. 2001; Nechushtan et al. 2001). The Bax and Bak homo-oligomers may coalesce into larger complexes (Mikhailov et al. 2003). In vitro, Bax or Bak oligomers can permeabilize mitochondria or protein-free liposomes, allowing passage of cytochrome $c$ (Antonsson et al. 2000; Saito et al. 2000) and even far larger molecules (Kuwana et al. 2002), but the nature of the "pores" remains controversial (Martinou and Green 2001; Kuwana et al. 2002; Newmeyer and Ferguson-Miller 2003).

\section{The mitochondrial 'poison cabinet'}

As illustrated in Figure 2, permeabilization of the outer mitochondrial membrane releases several cytotoxins (for review, see Wang 2001; Shi 2002), but whether any are essential for apoptosis is not yet established. Although cytochrome c activates Apaf-1, its absence only attenuates apoptosis (Li et al. 2000). The released Diablo/Smac

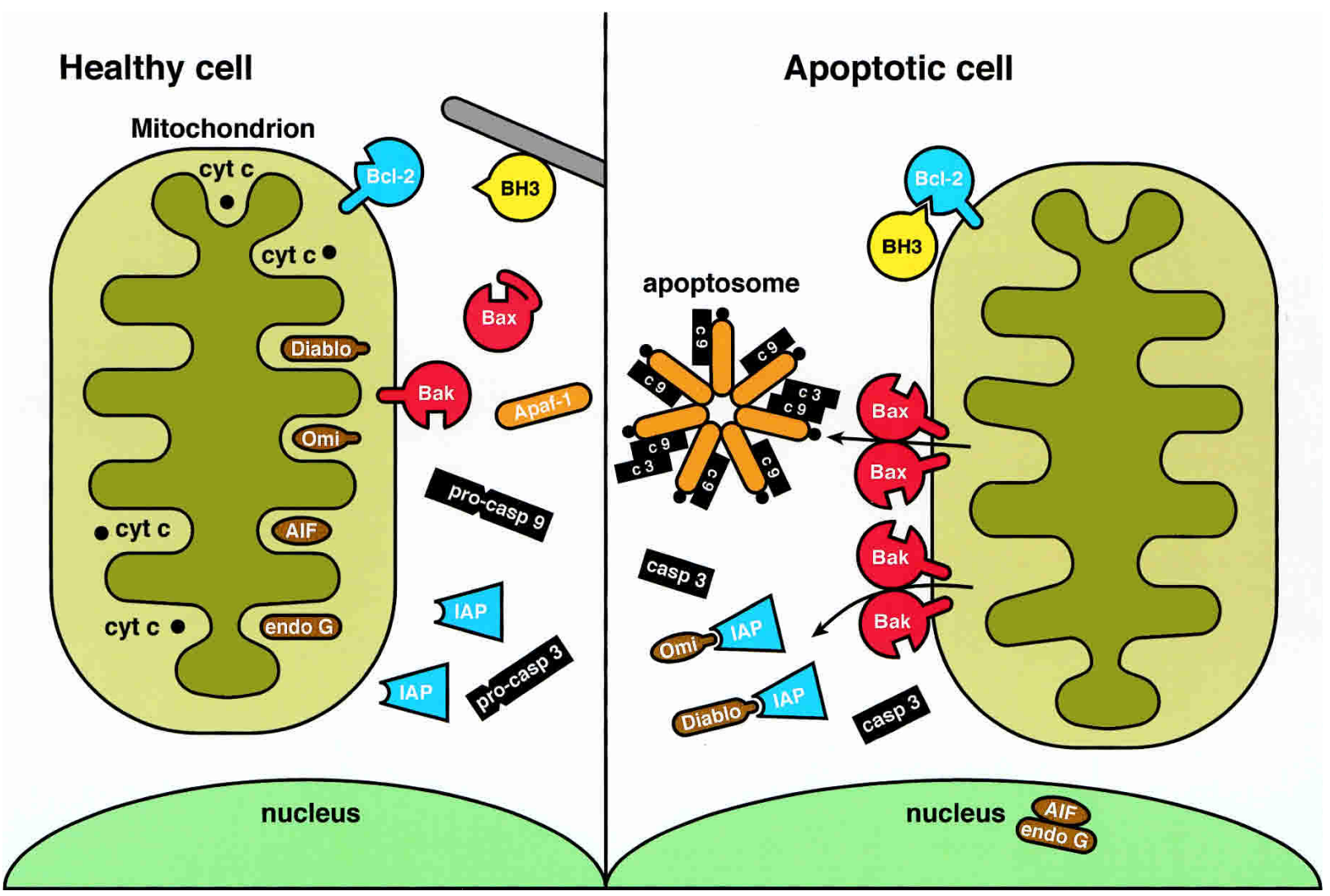

Figure 2. The role of mitochondrial outer membrane permeabilization in apoptosis. In a healthy cell, the caspases are all present as zymogens and the $\mathrm{BH} 3$-only proteins (BH3) are sequestered away from the Bcl-2-like pro-survival proteins (Bcl-2). After an apoptotic signal, the freed BH3-only proteins associate with Bcl-2 on mitochondria, and the recruitment of Bax and Bak into oligomers on the mitochondrial outer membrane then leads to its permeabilization. The released cytochrome c induces formation of the heptameric "apoptosome" of Apaf-1 and procaspase-9 (c9), which activates caspase-3 (c3). The released Diablo/Smac and Omi/Htr2 incapacitate the IAPs in the cytosol, whereas AIF and endonuclease G (endoG) enter the nucleus, where they may aid in DNA degradation. 
and Omi/HtrA2 prevent the inhibitor of apoptosis proteins (IAPs) from inhibiting the activity of processed caspases, but apoptosis is unaffected by loss of Smac/ Diablo (Okada et al. 2002), and although Omi/Htr2 might still block IAP action, inhibition of the IAPs does not initiate apoptosis (Verhagen et al. 2000). The flavoprotein AIF and endonuclease $G$ have been proposed to contribute to a "caspase-independent" cell death path involving chromatin condensation and large-scale DNA degradation (Penninger and Kroemer 2003). However, programmed cell death is retained in mice with minimal AIF activity (Klein et al. 2002). Moreover, the proposed nucleolytic role of AIF and endonuclease G needs further analysis, because all chromatin fragmentation was found to be entirely dependent on caspase-activated DNase (CAD) in one study (Kawane et al. 2003), albeit not in another (Samejima et al. 2001). In any case, cells unable to degrade their genome still undergo apoptosis and phagocytosis (Kawane et al. 2003).

The well studied invertebrate models for cell death provide little support for the view that mitochondrial disruption is required for apoptosis. Cytochrome $\mathrm{c}$ is most unlikely to have an apoptotic function in Caenorhabditis elegans: It does not activate the scaffold protein CED-4, which lacks the inhibitory WD40 repeats it targets in Apaf-1. More surprisingly, although the Drosophila Apaf-1 has WD40 repeats, apoptosis in flies also seems not to require cytochrome c release (Dorstyn et al. 2002; Zimmermann et al. 2002). Moreover, although IAP antagonists (e.g., Reaper) are critical in fly apoptosis (Martin 2002), none reside in mitochondria. Even though nematode mitochondria do contain endonuclease $\mathrm{G}$ and AIF orthologs, which may work together, their downregulation merely delays cell death (Parrish et al. 2001; Wang et al. 2002), and AIF release from mitochondria appears to require caspase activity in both worms (Wang et al. 2002) and mammals (Arnoult et al. 2002).

\section{Amplification role of the apoptosome}

The bedrock of the case for mitochondrial control of mammalian apoptosis has been that holo-cytochrome c, present only in mitochondria, is an essential cofactor for Apaf-1-mediated activation of caspase-9 and thence caspase-3 (Li et al. 1997; Wang 2001). But does the apoptosome account for all stress-induced apoptosis, that is, all apoptosis regulated by the Bcl-2 family? Initial reports on mice lacking either Apaf-1 (Cecconi et al. 1998; Yoshida et al. 1998) or caspase-9 (Hakem et al. 1998; Kuida et al. 1998) supported that view: The mice died near birth with enlarged brains, as do mice lacking caspase-3, and apoptosis of several cell types was found to be impaired in vitro. Recent findings, however, rule out an essential role for Apaf-1 and caspase-9 in stressinduced apoptosis of several cell types (Marsden et al. 2002). Unlike Bcl-2 overexpression or loss of Bim, the absence of Apaf-1 or caspase- 9 did not increase B or T lymphocyte numbers in vivo, indicating that their developmentally programmed death continued unabated. Moreover, in response to diverse insults against which
Bcl-2 protects, lymphocytes lacking either Apaf-1 or caspase-9 died at near normal rates and with all the hallmarks of apoptosis. Indeed, even postmitotic neurons that lack Apaf-1 die normally (Honarpour et al. 2001), and a few Apaf- $1^{-1-}$ mice become healthy adults (Honarpour et al. 2000).

Thus, in many cells, the apoptosome is dispensable for stress-induced apoptosis. Since the level of total caspase activity is markedly lower in its absence, the apoptosome must be an amplifier of the caspase cascade rather than a critical initiator of it (Marsden et al. 2002). Apparently the amplification is more important for ensuring the death of certain cell types (e.g., neuronal precursors) than others (e.g., lymphocytes). Further evidence that the Bcl-2 family has a broader role than preventing apoptosome activation is that Bcl-2 can protect embryonic stem cells lacking Apaf-1 from stress-imposed death (Haraguchi et al. 2000); that the deletion of lymphocytes with self-reactivity requires the Bcl-2 antagonist Bim (Bouillet et al. 2002) but not Apaf-1 (Hara et al. 2002); and that fibroblasts lacking both Bax and Bak are much more refractory to cytotoxic insults, including overexpression of BH3-only proteins, than those lacking Apaf-1 or caspase-9 (Cheng et al. 2001; Zong et al. 2001).

It has been argued that mitochondrial disruption is required to activate the caspases initiating apoptosis, because synthetic caspase inhibitors blocked cell death but not cytochrome $c$ release (Kluck et al. 1997; Bossy-Wetzel et al. 1998), but other data demonstrate that the mitochondrial breach can be triggered by caspases (Adrain et al. 2001; Gao et al. 2001; Lassus et al. 2002; Marsden et al. 2002). Thus, certain caspases may well be activated at other sites in the cell.

\section{Potential role of the ER in apoptosis}

The endoplasmic reticulum (ER) is receiving increased attention as a second compartment participating in stress-induced apoptosis. In the ER, quality control mechanisms ensure that only properly folded proteins are passed along the secretory pathway. Stress to the ER produced by disturbed glycosylation, misfolded proteins, perturbed calcium homeostasis, or glucose deprivation provokes the unfolded protein response, and persistence of this response induces necrosis or apoptosis (Ferri and Kroemer 2001; Kaufman 2002).

The ER is the major intracellular store of $\mathrm{Ca}^{2+}$ ions; their efflux from it is often associated with uptake into mitochondria. The flux of $\mathrm{Ca}^{2+}$ ions has been implicated in cell death, albeit often in conflicting findings. Although $\mathrm{Ca}^{2+}$ ions seem to signal between the ER and mitochondria, whether or how this promotes caspase activation is obscure (see below). One potential mediator of $\mathrm{Ca}^{2+}$ signaling is the $\mathrm{Ca}^{2+}$-binding annexin-5, recently shown to be required for apoptosis in response to certain insults (Hawkins et al. 2002). Because cells lacking annexin-5 failed to release cytochrome c from mitochondria, and chelators of $\mathrm{Ca}^{2+}$ ions protected wild-type cells, annexin-5 might transduce a critical $\mathrm{Ca}^{2+}$ signal from the ER needed for mitochondrial disruption. 
Increasing evidence suggests that Bcl-2 functions on the ER as well as mitochondria. Bcl-2 targeted specifically to the ER interrupted the cross-talk from the ER to mitochondria produced by ER stress and certain other stimuli (Häcki et al. 2000; Annis et al. 2001; Rudner et al. 2001) and even prevented activation of Bax localized to mitochondria, suggesting that Bcl-2 can control Bax activation through an intermediate (Thomenius et al. 2003).

Either Bax or Bak is required for ER stress-induced apoptosis (Wei et al. 2001; Zong et al. 2001), and recent findings suggest that both can function on the ER, where they also reside in certain cells (Scorrano et al. 2003; Zong et al. 2003). Bax and Bak are implicated in mobilization of $\mathrm{Ca}^{2+}$ from ER stores and its uptake into mitochondria (Nutt et al. 2002; Scorrano et al. 2003) and apparently can function directly on the ER to promote caspase-12 activation (Zong et al. 2003; see below). Indeed, a full apoptotic response to certain cytotoxic stimuli (e.g., etoposide) may require that Bax/Bak act both in the ER to discharge $\mathrm{Ca}^{2+}$ ions and in mitochondria to permeabilize its outer membrane (Scorrano et al. 2003; Zong et al. 2003). No escape of proteins from the ER, however, has been reported. The cardiolipin in the mitochondrial membrane may account for its greater permeabilization by Bax (Kuwana et al. 2002).

\section{Potential apoptotic roles of initiator caspases other than caspase-9}

Although stress-induced apoptosis does not always rely on caspase-9 and the apoptosome (see above), caspase activity does seem to be essential. The apoptosis of Apaf1-null hematopoietic cells was greatly retarded by a broad-spectrum caspase inhibitor, and the activated caspases detected included not only the executioner caspase- 7 but also caspase-1 and another presumptive initiator with the size expected for processed caspase-11 or caspase-12, pointing to a novel apoptotic pathway in which caspase-1 and probably other initiator caspases directly activate caspase-7 (Marsden et al. 2002). In some cells, caspase- 2 is essential (Lassus et al. 2002), but no single upstream initiator can have full responsibility, because apoptosis is not markedly impaired in mice lacking any one of these caspases (see below). Hence, apoptosis may typically be initiated by several initiator caspases acting redundantly, either upstream or independent of mitochondria (Marsden et al. 2002). Their potential roles (Table 1) will be considered in turn, and their intracellular locations are sketched in Figure 3.

\section{Caspase-12}

Mouse caspase-12 appears to have special roles at the ER. It resides on the cytoplasmic face of the ER (Fig. 3) and is activated by ER stress (Nakagawa and Yuan 2000; Nakagawa et al. 2000). Cells from mice deficient in caspase12 were partially resistant to ER stress-induced apoptosis but still succumbed to other death stimuli. For example, their cortical neurons were somewhat refractory to amyloid- $\beta$ protein but not to staurosporine or trophic factor deprivation (Nakagawa et al. 2000).

Although ER disturbances can lead to mitochondrial disruption (see above), some evidence may implicate a path from the ER independent of mitochondria. Thus, independently of Apaf-1, caspase-12 has been reported to specifically activate caspase-9, which can then cleave caspase-3 (Rao et al. 2002). Similarly, caspase-9 seems to be required for the death induced by Sendai virus, but its processing does not depend on Apaf-1, caspase-3, or caspase-8 (Bitzer et al. 2002). Hence, in some circumstances, caspase- 9 might be activated independently of the apoptosome.

As no clear human ortholog of caspase-12 has been identified (Table 1), it seems very likely that other initiator caspases, for example, perhaps caspase- 8 (see below) contribute to the ER stress response. Conversely, caspase- 12 can be activated by other stimuli, such as serum starvation (Kilic et al. 2002) and the protein synthesis inhibitor anisomycin (Hoppe et al. 2002). Interestingly, these treatments produced large complexes of caspase- 3 or caspase-12 that lacked detectable Apaf-1 and hence might represent novel types of apoptosome (Hoppe et al. 2002; Kilic et al. 2002).

How caspase-12 is activated is not known, although activation of Bax/Bak on the ER membrane may be necessary (Zong et al. 2003). It has been proposed that $\mathrm{m}$ calpain, a cysteine protease activated by calcium ions (see above), processes procaspase-12 (Nakagawa and Yuan 2000). Although this would potentially provide a mechanism for coupling ER stress through $\mathrm{Ca}^{2+}$ release to caspase-12 activation, the evidence for m-calpain involvement is very limited, and processing of other initiator caspases is not sufficient for their activation (Boatright et al. 2003). TRAF2, a factor that associates with death receptors, has also been reported to interact with procaspase-12 and promote its self-processing (Yoneda et al. 2001).

\section{Caspase-2}

Whether caspase-2 has any significant role in apoptosis has been unclear. In mice lacking caspase-2, the effects on apoptosis were limited (Bergeron et al. 1998): oocytes were more plentiful and proved refractory to cytotoxic drugs, and B lymphoblasts were somewhat resistant to granzyme B and perforin. With several stimuli, the death of thymocytes and neuronal cells was unaffected (O'Reilly et al. 2002). Significantly, however, in certain cells, caspase- 2 can initiate apoptosis upstream of mitochondria. In several transformed cell lines treated with genotoxic agents, RNA interference (RNAi) to caspase-2 or Apaf-1 showed that apoptosis required both proteins (Lassus et al. 2002). Caspase-2 must act upstream, because it was required for Bax translocation to mitochondria and cytochrome c release (Lassus et al. 2002; Robertson et al. 2002). Although caspase-2 apparently cannot process other caspases (Van de Craen et al. 1999; Guo et al. 2002), like caspase- 8 it can cleave Bid and hence may 


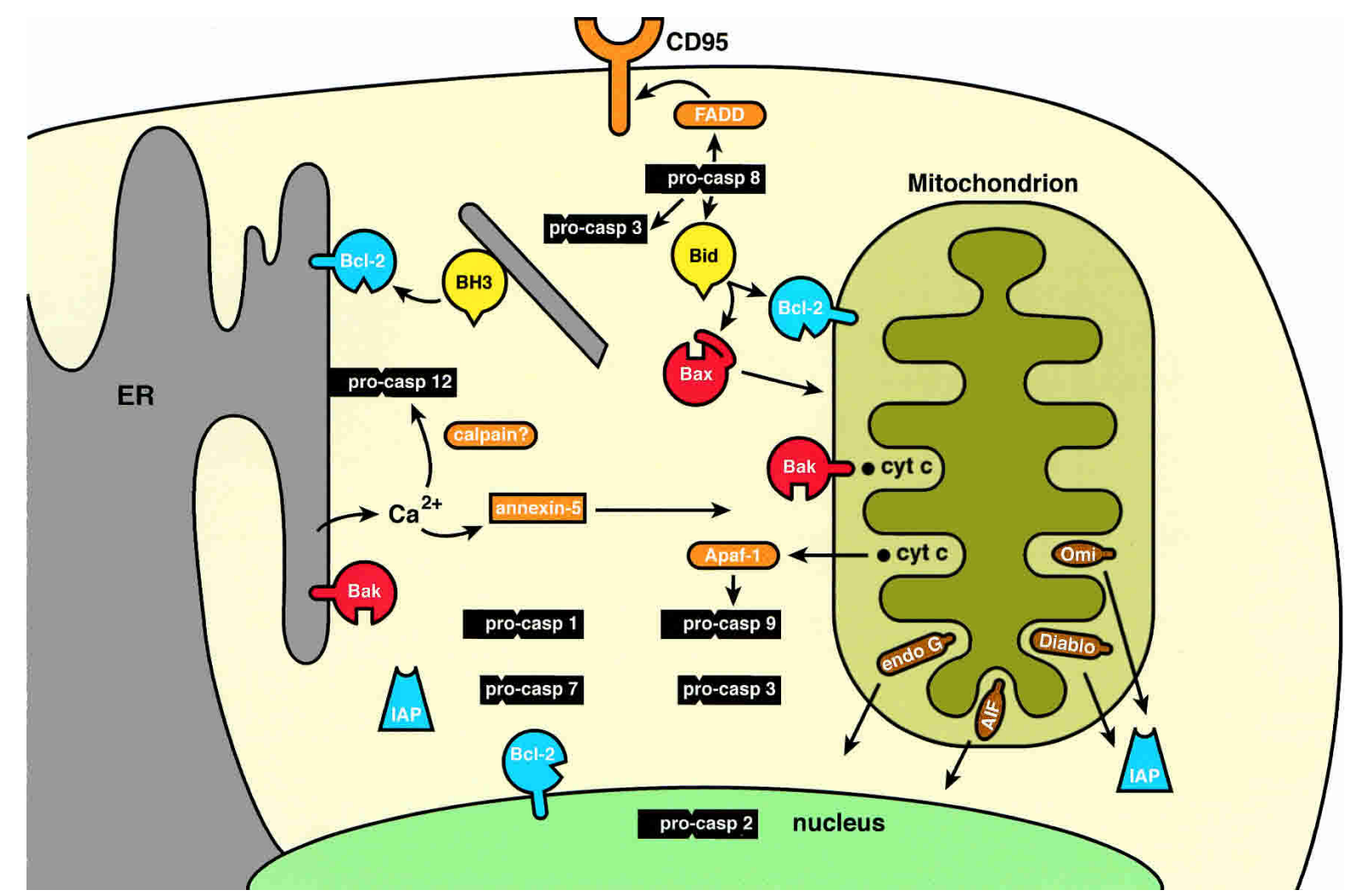

Figure 3. The location of caspases and their major regulators. Caspase- 2 is found in the nucleus and Golgi (not shown) and caspase-12 is found on the ER membrane, but the other initiator caspases (caspase-1, caspase-8, caspase-9, and caspase-11) and the executioner caspases-caspase-3, caspase-7, and caspase-6 (not shown)-are cytosolic. Bcl-2 family members either reside on the mitochondrial, ER, and nuclear membranes or congregate there during apoptosis. Caspase-8, which is activated by FADD on receptors of the TNF receptor family such as CD95 (Fas), directly activates caspase-3 but can also process Bid and thereby elicit mitochondrial damage. Caspase-9 is activated predominantly on the apoptosome after mitochondrial permeabilization (see Fig. 2). Caspase-12 may be activated via a $\mathrm{Ca}^{2+}$-mediated signal from the $\mathrm{ER}$, and $\mathrm{Ca}^{2+}$ ions and annexin-5 may convey signals from the ER to mitochondria. Previous suggestions that a proportion of certain caspase molecules are located within mitochondria have been strongly challenged (van Loo et al. 2002).

initiate mitochondrial disruption either through activation of Bax via truncated Bid (tBid), or by cleaving an unknown protein on the membrane (Guo et al. 2002).

Caspase- 2 activation is not well understood. Because its CARD can self-associate, caspase- 2 could be activated simply by release from an inhibitor (Butt et al. 1998). In incubated cell extracts, active caspase- 2 is found in a large (>700 kD) complex of unknown composition (Read et al. 2002). If a scaffold protein is involved in caspase-2 activation, one interesting candidate is DEFCAP (Nalp1/Card7/ $\mathrm{Nac}$, which has a CARD that interacts with that of procaspase-2, a nucleotide-binding domain, a leucine-rich region, and an N-terminal pyrin domain (Hlaing et al. 2001). Alternatively, a potential adaptor is RAIDD/CRADD (Duan and Dixit 1997; Shearwin-Whyatt et al. 2000).

A puzzling feature of caspase- 2 is its unique localization (Fig. 3), predominantly in the nucleus and the Golgi (O'Reilly et al. 2002). Perhaps the nuclear localization hints at a special role for caspase- 2 in the response to DNA damage. It has been argued that caspase- 2 could trigger apoptosis directly from the nucleus, perhaps by cleaving a substrate like Bid, which is small enough to diffuse through the nuclear pores (Paroni et al. 2002).

\section{Caspase-1 and caspase-11}

Caspase-1 and caspase-11 of mice, like the corresponding human caspase- 1 and caspase- 5 , are encoded by adjacent genes within a small cluster (Table 1). Their primary function is thought to be processing the precursors of the inflammatory cytokines IL-1 $\beta$ and IL-18. Mice lacking either caspase develop normally but cannot make the mature cytokines and are highly resistant to septic shock (Kuida et al. 1995; Li et al. 1995). Certain observations, however, hint at roles in apoptosis. When caspase-11 is induced by lipopolysaccharide (as is human caspase-5), it contributes to the activation of caspase- 3 and caspase-7 as well as caspase-1 (Kang et al. 2002), and caspase-1 can also process the executioner caspases in vitro (Van de Craen et al. 1999). Furthermore, oligodendrocytes lacking caspase-11 are somewhat refractory to cytotoxic cytokines (Hisahara et al. 2001), neutrophils lacking caspase-1 die more slowly in culture (Rowe et al. 2002) and, as noted above, dying Apaf-1-null hematopoietic cells contain active caspase-1 (Marsden et al. 2002).

The apoptotic potential of caspase-1 has been exploited by pathogens. The invasin proteins of Shigella 
(IpaB) and Salmonella (SipB) trigger apoptosis in macrophages by binding to procaspase- 1 and promoting its selfprocessing, and the ensuing rapid cell death requires caspase-1 (Hilbi et al. 1998; Hersh et al. 1999). SipB also activates caspase-2, which seems to drive the somewhat slower death of macrophages lacking caspase-1 (Jesenberger et al. 2000).

In uninfected cells, how caspase- 1 might be activated for apoptosis is unclear. If a scaffold similar to Apaf- 1 is required, the best current candidate is Ipaf (Card12/Clan; Poyet et al. 2001); as well as a CARD that interacts with that of Apaf-1, Ipaf has a nucleotide-binding domain and a C-terminal leucine-rich regulatory domain, removal of which induces caspase-1-dependent apoptosis. Alternatively, caspase-1 might be activated by the adaptor protein ASC (Pycard/Tms1), which has both a CARD and a pyrin domain (Srinivasula et al. 2002), or by a more complex scaffold involving several proteins, akin to the proposed "inflammasome", in which human caspase-1 and caspase- 5 are bridged by two proteins with both CARD and pyrin domains (Martinon et al. 2002). Different activators might target caspase-1 for inflammatory or apoptotic duty.

\section{Caspase-8}

Caspase- 8 and its adaptor FADD are required for the apoptosis elicited by all death receptors (Strasser et al. 2000; Ashkenazi 2002). Once activated, caspase-8 can initiate robust proteolysis in many cell types (e.g., lymphocytes) by directly processing caspase-3 (Fig. 3). Alternatively, in certain cell types (e.g., hepatocytes), caspase- 8 acts in addition by cleaving Bid (Yin et al. 1999), which can then promote mitochondrial permeabilization (see below) and thus caspase-9 activation (Fig. 3). The physiological significance of this alternative pathway is uncertain, however, because loss of Bid does not disturb tissue homeostasis (Yin et al. 1999), and neither Bcl-2 overexpression in lymphocytes (Strasser et al. 1995) nor loss of both Bax and Bak in fibroblasts (Wei et al. 2001) impedes the killing elicited by death receptors.

Although cells lacking caspase- 8 or FADD function are refractory to death receptor engagement, they die normally with every other type of cytotoxic insult so far tested (Newton et al. 1998; Varfolomeev et al. 1998; Salmena et al. 2003). It is therefore tempting to regard the FADD-caspase-8/10 pathway as dedicated entirely to death receptor responses. A redundant role in some forms of stress-induced apoptosis, however, cannot be entirely ruled out. Indeed, some results implicate caspase- 8 as well as caspase-12 in apoptosis induced by ER stress (Breckenridge et al. 2003; Jimbo et al. 2003; Yamaguchi et al. 2003).

\section{Interplay of Bcl-2 family members in commitment to apoptosis}

The roles of opposing Bcl-2 family members in tissue homeostasis have been established genetically (Cory et al. 2003). For example, in the lymphoid compartment, excess cells result from overexpression of Bcl-2, loss of the BH3-only protein Bim (Bouillet et al. 1999), or elimination of both Bax and Bak (Lindsten et al. 2000; Rathmell et al. 2002). Hence, at least in those cells, Bim, Bcl-2, and Bax/Bak constitute a single essential pathway to cell death (see below). Bim and other $\mathrm{BH} 3$-only proteins clearly lie upstream of $\mathrm{Bax} / \mathrm{Bak}$, because they cannot kill cells lacking both Bax and Bak /Cheng et al. 2001; Zong et al. 2001).

The BH3-only proteins trigger apoptosis in response to developmental cues, insufficient trophic support, and intracellular damage (Huang and Strasser 2000; Bouillet and Strasser 2002; Puthalakath and Strasser 2002). In C. elegans, the death of all 131 somatic cells fated to die during development requires the $\mathrm{BH} 3$-only protein EGL-1 (Conradt and Horvitz 1998). The eight or more members in mammals (Fig. 1) allow more specialization. For example, loss of Bim renders cells refractory to cytokine deprivation, calcium flux, Taxol, and the T-cell receptor signals that kill self-reactive lymphocytes, but not markedly to $\gamma$-irradiation (Bouillet et al. 1999, 2002). Conversely, the p53-induced Noxa and Puma may well mediate the response to genotoxic damage, as demonstrated for Puma in a cancer cell line (Yu et al. 2003)

Premature activity of the BH3-only proteins is precluded by diverse mechanisms (Bouillet and Strasser 2002; Puthalakath and Strasser 2002; Cory et al. 2003). Whereas Noxa, Puma, Hrk/DP5, and EGL-1 are controlled primarily at the transcriptional level, Bad is regulated by its phosphorylation and sequestration by 14-3-3 proteins, and Bid by the need for cleavage to expose its $\mathrm{BH} 3$ domain. Evidence that Bim and Bmf are normally sequestered to the microtubules and actin cytoskeleton, respectively, has led to the view that $\mathrm{BH} 3$-only proteins can serve as sentinels for damage to particular intracellular structures (Puthalakath et al. 1999, 2001).

How Bax and Bak are activated is uncertain. It has been proposed that Bid activates Bax and Bak, as well as inactivates pro-survival relatives (Desagher et al. 1999; Gross et al. 1999; Wei et al. 2000). Cleavage of Bid, for example by caspase-8, and myristoylation of its C-terminal fragment (p15 tBid) promotes its migration to mitochondria (Li et al. 1998; Luo et al. 1998; Zha et al. 2000). If Bak (or Bax) is present (Wei et al. 2000; Kuwana et al. 2002), tBid then triggers cytochrome $c$ release and apoptosis, apparently by inducing Bax and Bak to oligomerize and breach membrane integrity. Any direct association of tBid with them must be transient, however, because they do not colocalize on the membrane (Nechushtan et al. 2001) and Bid is not usually detectable in Bax or Bak oligomers (Wei et al. 2000; Grinberg et al. 2002), although it may bind weakly to Bak (Ruffolo and Shore 2003). Whether tBid requires another mitochondrial protein to trigger Bax oligomerization is controversial (Kuwana et al. 2002; Roucou et al. 2002). Hence, it is not ruled out that tBid acts mainly by inactivating pro-survival relatives, or by facilitating Bax/Bak effects on the membrane without dimerizing with Bax or Bak. In any case, Bid cannot be uniquely responsible for Bax/Bak activation: Although the absence of Bid renders 
hepatocytes refractory to Fas-mediated apoptosis, it does not noticeably affect tissue homeostasis (Yin et al. 1999) nor impede stress-induced apoptosis (Wei et al. 2001).

Conceivably, the activation of Bax and Bak might normally be restrained by other proteins. Bax, for example, might be sequestered in the cytosol of healthy cells by one of several putative new binding partners (Guo et al. 2003; Nomura et al. 2003; Sawada et al. 2003). Similarly, in healthy but not in apoptotic cells, a small proportion of Bak molecules are bound to VDAC2, which forms a pore in the mitochondrial outer membrane /Cheng et al. 2003). The physiological relevance of all these interactions, however, remains to be established.

In principle, the different factions of the Bcl-2 family could interact in several ways to set the threshold for cell death (Fig. 4):

(A) Bcl-2 sequesters $\mathrm{BH} 3$ ligands from Bax/Bak. In this model (Fig. 4A), the Bcl-2-like proteins principally capture activated $\mathrm{BH} 3$-only proteins, preventing their activation of Bax or Bak (Cheng et al. 2001; Zong et al. 2001). For example, if a BH3-only protein can bind to Bax/Bak but has a higher affinity for Bcl-2, it must titrate Bcl-2 before it can activate Bax. Some results with tBid may be compatible with this model; for example, tBid, or a Bid $\mathrm{BH} 3$ peptide, induced Bax to permeabilize protein-free liposomes (Kuwana et al. 2002). Tellingly, however, no binding to Bax is demonstrable with most $\mathrm{BH} 3$-only proteins, particularly under conditions that avoid non-ionic detergents, which are known to "open" the Bax structure (Hsu and Youle 1998; Suzuki et al. 2000). Also, this model predicts that the threshold for apoptosis would fall with the concentration of Bcl-2-like molecules, but cell death is not discernibly increased in mice retaining a single allele of $b c l-2$, or of any of its homologs (Cory et al. 2003).

(B) BH3-only proteins target Bcl-2 and ablate its inhi-

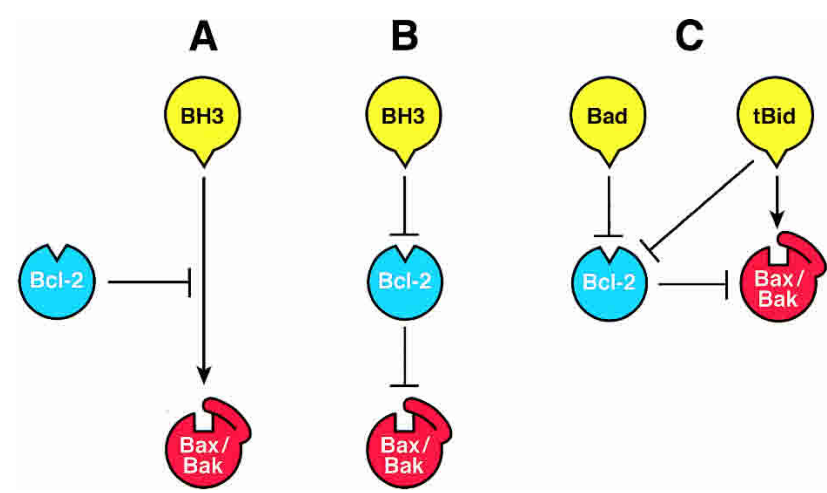

Figure 4. Three models for the functional relationship of the different factions of the Bcl-2 family. (A) A model in which the $\mathrm{BH} 3$-only proteins $(\mathrm{BH} 3)$ directly engage $\mathrm{Bax} / \mathrm{Bak}$, once they have overwhelmed Bcl-2 and its pro-survival homologs. (B) A model in which the $\mathrm{BH} 3$-only proteins (BH3) target only Bcl-2, which prevents activation of Bax/Bak (either directly or indirectly) until it is itself inactivated. $(C)$ A model in which certain $\mathrm{BH} 3$-only proteins (e.g., Bad) can engage only Bcl-2, whereas others (e.g., tBid) can bind to both, so that both classes of BH3only proteins must be activated. bition of Bax. In this model (Fig. 4B), the BH3-only proteins promote Bax activation only via their ability to inactivate the Bcl-2-like proteins. Certainly, the known $\mathrm{BH} 3-$ only proteins (or BH3 peptides) do bind to the prosurvival proteins, often with low nM affinity (Letai et al. 2002; Hinds et al. 2003). For example, the major isoforms of Bim bind strongly to several Bcl-2-like proteins but not discernibly to Bax (O'Connor et al. 1998). This model also accounts for the widespread observation that Bcl-2 overexpression prevents activation of Bax and Bak.

(C) Certain BH3-only proteins activate Bax whereas others inactivate Bcl-2. In this model (Fig. 4C), BH3-only proteins of one subset, for example tBid, can directly activate Bax/Bak but are first sequestered by Bcl-2, until displaced by members of the second subset, for example Bad, which bind specifically to the pro-survival proteins with high affinity (Letai et al. 2002). This model arose from evidence that a Bad $\mathrm{BH} 3$ peptide induced cytochrome c release from mitochondria only in the presence of $\mathrm{tBid}$ or a Bid $\mathrm{BH} 3$ peptide (Letai et al. 2002), but no quantitative data on binding of $\mathrm{BH} 3$ peptides to Bax has been reported. Also, in this model apoptosis would seem to require activation of both the two proposed classes of $\mathrm{BH} 3$-only protein, but single $\mathrm{BH} 3$-only proteins such as Bad are a potent apoptotic stimulus (Cheng et al. 2001; Zong et al. 2001).

Do the Bcl-2-like proteins function primarily by keeping $\mathrm{BH} 3$-only proteins away from Bax and Bak, as might be inferred from models $\mathrm{A}$ and $\mathrm{C}$ in Figure 4? That is unlikely, because Bcl-w lacking only 10 C-terminal residues is biologically inactive, even though it still binds BH3-only proteins avidly (Hinds et al. 2003). Moreover, CED-9, the worm homolog of Bcl-2, does not function merely by binding EGL-1 (see below). If it did, reduction in that ability would impair its survival activity. Instead, a point mutant of CED-9 with reduced affinity for EGL-1 has increased survival activity in the worm (del Peso et al. 2000; Parrish et al. 2000). The apoptotic role of Bcl2-like proteins is therefore unlikely to be confined to engaging $\mathrm{BH} 3$-only proteins. For the mammalian proteins, one additional function clearly is preventing activation of the Bax-like proteins, but whether that involves direct association is problematic, because interaction is usually detectable only with detergent conditions that alter the Bax structure (Hsu and Youle 1998). Interestingly, however, the viral Bcl-2 homolog E1B 19K has been proposed to act entirely by sequestering activated Bax (Perez and White 2000). The Bcl-2-like proteins might act instead by sequestering a membrane protein needed for Bax/Bak activation.

\section{How might the Bcl-2 family control the activation of caspases?}

Nobel prize-winning genetic studies in C. elegans (Horvitz 1999) laid the foundation for a simple protein association model for the survival function of CED-9 (Fig. 5). In a healthy cell, both CED-9 and CED-4 reside on mitochondria (Chen et al. 2000). CED-9 can bind CED-4 and thereby prevent it from activating the caspase CED- 


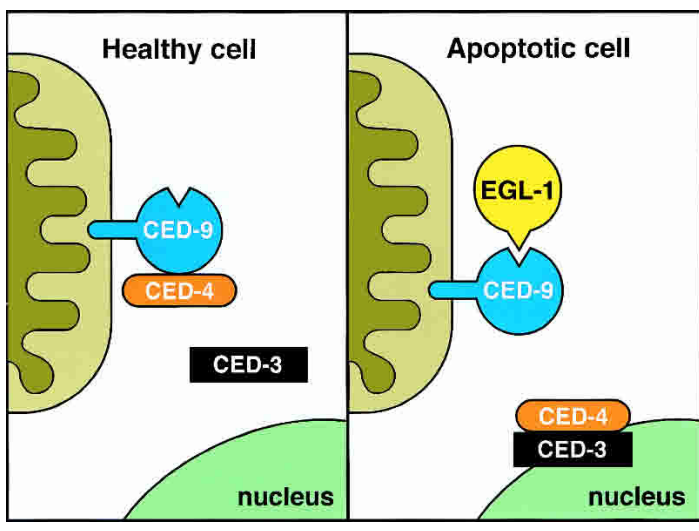

Figure 5. The sequestration model for pro-survival function in the nematode C. elegans. The sole worm Bcl-2 homolog CED-9, which resides on mitochondria, is proposed to sequester the scaffold protein CED-4, preventing it from activating the caspase CED-3. When EGL-1 is synthesized, it displaces CED-4 from CED-9, and CED-4 moves to the nuclear envelope and presumably can then oligomerize and activate CED-3.

3. Cells fated to die synthesize EGL-1, which binds to CED-9 and displaces CED-4 (Conradt and Horvitz 1998). CED-4 then moves to the nuclear envelope (Chen et al. 2000), presumably in association with CED-3.

The evolutionary conservation of the cell death program and the ability of human Bcl-2 to convey survival in C. elegans (Vaux et al. 1992) argue that Bcl-2 should function very similarly to CED-9 (Fig. 5). Hence, it has been suggested (e.g., Hausmann et al. 2000; Strasser et al. 2000) that Bcl-2 might act, at least in part, by sequestering a mammalian homolog of CED-4. That cannot be Apaf-1, because Apaf-1 does not associate or localize with Bcl-2-like proteins (Moriishi et al. 1999; Hausmann et al. 2000). Several other mammalian proteins that resemble CED-4 are now known (see above), but none has yet been reported to interact with Bcl-2.

Although the sequestration model is elegantly simple, recent data in the worm indicate that it does not fully account for CED-9 function. Significantly, neither release of CED-4 from CED-9 nor translocation of CED-4 to the nuclear envelope is sufficient for cell death (H.R. Horvitz, pers. comm.). CED-9 must therefore have an unknown survival function independent of CED-4 association. One potential clue is that, relative to $\mathrm{Bcl}-2$, CED-9 possesses an extra $\mathrm{N}$-terminal domain that contains two caspase cleavage sites required for its full survival function (Xue and Horvitz 1997). Hence, CED-9 might act as a pseudosubstrate and convey survival in part by directly inhibiting CED-3 activity (Xue and Horvitz 1997). CED-9 might also help to maintain mitochondrial integrity. Since there is no Bax ortholog in $C$. elegans, that putative function presumably would be mediated through its association with an unidentified protein on the outer membrane.

For mammalian cells, the major gaps in current knowledge also preclude a definitive model for the control of stress-induced apoptosis, but some possibilities can be outlined. In a speculative model (Fig. 6), Bcl-2 not only interacts with $\mathrm{BH} 3$-only proteins but may also have two effector functions. One is to prevent activation of certain upstream initiator caspases, for example, caspases-1 and 2, perhaps by restraining "caspase activators" such as their presumptive scaffold proteins, as CED-9 is thought to do in the worm (Fig. 5). When these caspases are activated, they may directly process effector caspases such as caspase-7 and also promote organelle perturbation by activating $\mathrm{Bax}$ and $\mathrm{Bak}$, perhaps via cleavage of Bid or proteins akin to it. The second postulated effector function of Bcl-2, to prevent Bax and Bak activation (Fig. 6), might be mediated by interaction with them, although the evidence for direct association is weak (Cory et al. 2003). Alternatively, Bcl-2 might control an unknown "Bax/Bak activator", such as a membrane protein that can facilitate Bax/Bak oligomerization. Once Bax and Bak are activated, the model assumes that they perturb not only the mitochondrial membrane but also that of the ER. Their major function on the ER may be the release of $\mathrm{Ca}^{2+}$ ions and activation of caspase12 , paralleling their role in the release of cytochrome c

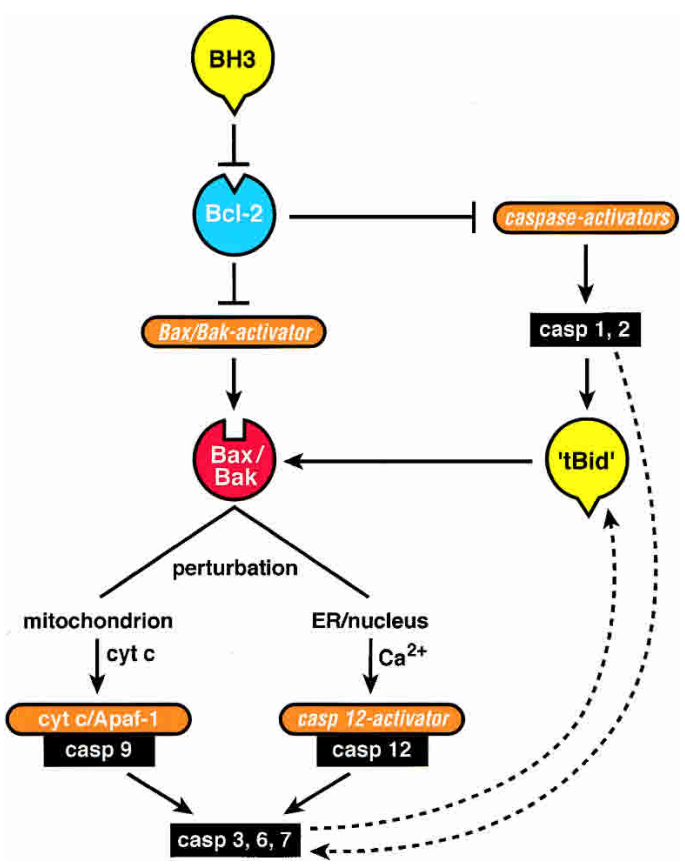

Figure 6. A speculative model for the control of caspase activation by the Bcl-2 family. Features of the model are that certain initiator caspases (perhaps caspase-1 and caspase-2) are envisioned to be activated upstream of organelle perturbation and others (caspase-9 and caspase-12) downstream; that Bcl-2 (and its pro-survival relatives) are presumed to regulate the former set fairly directly and the latter set by preventing Bax/Bak activation; and that Bax/Bak perturbs the ER/nuclear membrane as well as the outer mitochondrial membrane. Whether the ER/ nuclear pathway predominantly functions independently of the mitochondrion or acts mainly through it is uncertain. "BH3" denotes a $\mathrm{BH} 3$-only protein that engages a Bcl-2-like pro-survival protein; "tBid" indicates a molecule that, after caspase cleavage, can activate Bax or Bak. Italics indicate the most speculative features of the model, namely the putative activators of several caspases and of Bax/Bak. 
from the mitochondrion and the activation of caspase-9 (Fig. 2). Once the effector caspases have been processed, they undoubtedly will disturb the organelles further.

\section{Conclusions and conundrums}

The findings reviewed here indicate that the regulation of programmed cell death and stress-induced apoptosis is likely to be much more complex than previously envisioned. The notion that all forms of intracellular stress governed by the Bcl-2 family rely upon mitochondrial disruption and activation of caspase-9 on the apoptosome now seems difficult to maintain. Rather than initiating the caspase cascade, in many cells the apoptosome may primarily boost the total level of caspase activity (Marsden et al. 2002). That elevation is undoubtedly needed for the demise of certain cell types but not for many others, presumably because the lower levels generated by other pathways suffice.

Each of the initiator caspases clearly can trigger cellular demolition under certain circumstances, but identifying the major physiological initiators will require more genetic analysis. The best candidates seem to be caspase1 , caspase-2, and caspase-12, but the very modest consequences for apoptosis of disrupting the individual genes suggests that several initiator caspases with largely redundant function may be activated (Marsden et al. 2002). Ablation of more than one initiator caspase will be required to test this hypothesis.

How the initiator caspases other than caspase- 8 and caspase-9 are activated is poorly understood. Although candidate scaffold or adaptor proteins have been identified (Table 1), no gene knockout or other data yet incorporate them into a cytotoxic signaling pathway. Because dimerization suffices for activation of initiator caspases (Boatright et al. 2003), structures much simpler than the heptameric apoptosome (Fig. 2) might be used. Some very recent data implicate serine proteases at an early stage of stress-induced apoptosis (de Bruin et al. 2003; Egger et al. 2003).

In the Bcl-2 family network (Figs. 1, 4), the initiating role of the $\mathrm{BH} 3$-only proteins seems accepted, but more insight is needed into which stress signals each of these proteins transduces, how each registers particular stresses, and how their association with the Bcl-2-like proteins cancels survival activity. For the pro-survival family members, it would help to know whether their interactions with the $\mathrm{BH} 3$-proteins are promiscuous or, more likely, show some specificity, whether they control Bax activation by direct contact or through intermediates, and whether their survival function involves any engagement of nonfamily members, as that of CED-9 does (Fig. 5). The essential role of Bax or Bak for apoptosis of many cells is established, but their activation remains poorly understood; in particular, the issues of whether it involves direct engagement by $\mathrm{BH} 3$-only proteins (Fig. 4), whether other proteins sequester Bax in the cytosol, and whether additional proteins on the membrane facilitate or hamper Bax/Bak oligomerization remain controversial, as does the mechanism of mitochon- drial membrane permeabilization (Newmeyer and Ferguson-Miller 2003).

Increasing evidence implicates ER as well as mitochondrial disturbance in apoptosis. Although both Bcl2-like proteins and Bax and Bak probably function on the ER (Fig. 3), the ER perturbation seems less dramatic: The release of calcium ions is implicated, but their role in apoptosis remains poorly understood. In addition to the cross-talk between the ER and mitochondria, an independent pathway from the ER to cell death may exist, probably involving caspase-12 (Fig. 6; Zong et al. 2003).

The central question of how the Bcl-2 family governs caspase activation remains largely a mystery. If Bax and Bak do function by perturbing the ER and mitochondrial membranes, the profound block to apoptosis in many cell types that lack both these proteins argues that the organelle perturbation is crucial. Hence, Bcl-2 might act entirely by preventing perturbation of these organelles. If so, Bcl-2 might not control the activation of certain upstream initiator caspases, just as it cannot prevent caspase- 8 activation by death receptors. On the other hand, in C. elegans, which has no protein similar to Bax or Bak, the Bcl-2 ortholog CED-9 seems to function in part by more directly controlling caspase activation (Fig. $5)$. Hence, the Bcl-2-like proteins might block activation of certain upstream caspases as well as prevent Bax and Bak from disturbing the organelles and thereby inducing the activation of additional initiator caspases (Fig. 6).

In the 15 years since the discovery of the survival function of Bcl-2 (Vaux et al. 1988), an immense amount has clearly been learned about its biological role, its many relatives, and the caspase demolition machinery, and the knowledge gleaned has opened the prospect of directly targeting the apoptotic machinery for therapeutic benefit (Cory and Adams 2002; Cory et al. 2003). Nevertheless, central questions remain about how the interaction of these remarkable networks controls the life and death of cells.

\section{Acknowledgments}

This review benefited greatly from many discussions with colleagues, particularly my senior colleagues Suzanne Cory, Andreas Strasser, and David Huang. Ruth Kluck and Philippe Bouillet also made helpful comments on the manuscript. The author's own research is supported by the National Health and Medical Research Council (Program Grant ID no. 257502), the Leukemia and Lymphoma Society (Specialized Center of Research), and the National Cancer Institute (CA43540 and CA80188).

\section{References}

Acehan, D., Jiang, X., Morgan, D.G., Heuser, J.E., Wang, X., and Akey, C.W. 2002. Three-dimensional structure of the apoptosome: Implications for assembly, procaspase-9 binding, and activation. Mol. Cell 9: 423-432.

Adrain, C., Creagh, E.M., and Martin, S.J. 2001. Apoptosis-associated release of Smac/DIABLO from mitochondria requires active caspases and is blocked by Bcl-2. EMBO J. 20: 6627-6636.

Annis, M.G., Zamzami, N., Zhu, W., Penn, L.Z., Kroemer, G., Leber, B., and Andrews, D.W. 2001. Endoplasmic reticulum localized Bcl-2 prevents apoptosis when redistribution of cy- 
tochrome c is a late event. Oncogene 20: 1939-1952.

Antonsson, B., Montessuit, S., Lauper, S., Eskes, R., and Martinou, J.C. 2000. Bax oligomerization is required for channelforming activity in liposomes and to trigger cytochrome c release from mitochondria. Biochem. J. 345 Pt 2: 271-278.

Antonsson, B., Montessuit, S., Sanchez, B., and Martinou, J.C. 2001. Bax is present as a high molecular weight oligomer/ complex in the mitochondrial membrane of apoptotic cells. J. Biol. Chem. 276: 11615-11623.

Arnoult, D., Parone, P., Martinou, J.C., Antonsson, B., Estaquier, J., and Ameisen, J.C. 2002. Mitochondrial release of apoptosis-inducing factor occurs downstream of cytochrome $c$ release in response to several proapoptotic stimuli. J. Cell Biol. 159: 923-929.

Ashkenazi, A. 2002. Targeting death and decoy receptors of the tumour-necrosis factor superfamily. Nat. Rev. Cancer 2: $420-430$

Bergeron, L., Perez, G.I., Macdonald, G., Shi, L., Sun, Y., Jurisicova, A., Varmuza, S., Latham, K.E., Flaws, J.A., Salter, J.C., et al. 1998. Defects in regulation of apoptosis in caspase-2deficient mice. Genes \& Dev. 12: 1304-1314.

Bitzer, M., Armeanu, S., Prinz, F., Ungerechts, G., Wybranietz, W., Spiegel, M., Bernlohr, C., Cecconi, F., Gregor, M., Neubert, W.J., et al. 2002. Caspase-8 and Apaf-1-independent caspase-9 activation in Sendai virus-infected cells. J. Biol. Chem. 277: 29817-29824.

Boatright, K.M., Renatus, M., Scott, F.L., Sperandio, S., Shin, H., Pedersen, I.M., Ricci, J.E., Edris, W.A., Sutherlin, D.P., Green, D.R., et al. 2003. A unified model for apical caspase activation. Mol. Cell 11: 529-541.

Bossy-Wetzel, E., Newmeyer, D.D., and Green, D.R. 1998. Mitochondrial cytochrome $c$ release in apoptosis occurs upstream of DEVD-specific caspase activation and independently of mitochondrial transmembrane depolarization. EMBO J. 17: 37-49.

Bouillet, P. and Strasser, A. 2002. BH3-only proteins-Evolutionarily conserved proapoptotic Bcl-2 family members essential for initiating programmed cell death. J. Cell Sci. 115: 1567-1574.

Bouillet, P., Metcalf, D., Huang, D.C.S., Tarlinton, D.M., Kay, T.W.H., Köntgen, F., Adams, J.M., and Strasser, A. 1999. Proapoptotic Bcl-2 relative Bim required for certain apoptotic responses, leukocyte homeostasis, and to preclude autoimmunity. Science 286: 1735-1738.

Bouillet, P., Purton, J.F., Godfrey, D.I., Zhang, L.-C., Coultas, L., Puthalakath, H., Pellegrini, M., Cory, S., Adams, J.M., and Strasser, A. 2002. BH3-only Bcl-2 family member Bim is required for apoptosis of autoreactive thymocytes. Nature 415: 922-926.

Breckenridge, D.G., Stojanovic, M., Marcellus, R.C., and Shore, G.C. 2003. Caspase cleavage product of BAP31 induces mitochondrial fission through endoplasmic reticulum calcium signals, enhancing cytochrome $c$ release to the cytosol. $J$. Cell Biol. 160: 1115-1127.

Butt, A.J., Harvey, N.L., Parasivam, G., and Kumar, S. 1998. Dimerization and autoprocessing of the Nedd2 (caspase-2) precursor requires both the prodomain and the carboxyl-terminal regions. J. Biol. Chem. 273: 6763-6768.

Cecconi, F., Alvarez-Bolado, G., Meyer, B.I., Roth, K.A., and Gruss, P. 1998. Apaf-1 (CED-4 homologue) regulates programmed cell death in mammalian development. Cell 94: 727-737.

Chen, F., Hersh, B.M., Conradt, B., Zhou, Z., Riemer, D., Gruenbaum, Y., and Horvitz, H.R. 2000. Translocation of C. elegans CED-4 to nuclear membranes during programmed cell death. Science 287: 1485-1489.
Cheng, E.H., Wei, M.C., Weiler, S., Flavell, R.A., Mak, T.W., Lindsten, T., and Korsmeyer, S.J. 2001. BCL-2, BCL- $\mathrm{x}_{\mathrm{L}}$ sequester $\mathrm{BH} 3$ domain-only molecules preventing BAX- and BAK-mediated mitochondrial apoptosis. Mol. Cell 8: 705711.

Cheng, E.H., Sheiko, T.V., Fisher, J.K., Craigen, W.J., and Korsmeyer, S.J. 2003. VDAC2 inhibits BAK activation and mitochondrial apoptosis. Science 301: 513-517.

Conradt, B. and Horvitz, H.R. 1998. The C. elegans protein EGL-1 is required for programmed cell death and interacts with the Bcl-2-like protein CED-9. Cell 93: 519-529.

Cory, S. and Adams, J.M. 2002. The Bcl2 family: Regulators of the cellular life-or-death switch. Nat. Rev. Cancer 2: 647656.

Cory, S., Huang, D.C.S., and Adams, J.M. 2003. The Bcl-2 Family: Roles in cell survival and oncogenesis. Oncogene (in press).

Cuconati, A. and White, E. 2002. Viral homologs of BCL-2: Role of apoptosis in the regulation of virus infection. Genes \& Dev. 16: 2465-2478.

de Bruin, E., Meersma, D., de Wilde, J., den Otter, I., Schipper, E., Medema, J., and Peltenberg, L. 2003. A serine protease is involved in the initiation of DNA damage-induced apoptosis. Cell Death Diff. 10: 1204-1212

del Peso, L., González, V.M., Inohara, N., Ellis, R.E., and Núñez, G. 2000. Disruption of the CED-9/CED-4 complex by EGL-1 is a critical step for programmed cell death in C. elegans. I. Biol. Chem. 275: 27205-27211.

Desagher, S., Osen-Sand, A., Nichols, A., Eskes, R., Montessuit, S., Lauper, S., Maundrell, K., Antonsson, B., and Martinou, J.-C. 1999. Bid-induced conformational change of Bax is responsible for mitochondrial cytochrome $\mathrm{c}$ release during apoptosis. J. Cell Biol. 144: 891-901.

Dorstyn, L., Read, S., Cakouros, D., Huh, J.R., Hay, B.A., and Kumar, S. 2002. The role of cytochrome $c$ in caspase activation in Drosophila melanogaster cells. J. Cell Biol. 156: 1089-1098.

Duan, H. and Dixit, V.M. 1997. RAIDD is a new 'death' adaptor molecule. Nature 385: 86-89.

Egger, L., Schneider, J., Rheme, C., Tapernoux, M., Hacki, J., and Borner, C. 2003. Serine proteases mediate apoptosis-like cell death and phagocytosis under caspase-inhibiting conditions. Cell Death Diff. 10: 1188-1203.

Enari, M., Sakahira, H., Yokoyama, H., Okawa, K., Iwamatsu, A., and Nagata, S. 1998. A caspase-activated DNase that degrades DNA during apoptosis, and its inhibitor ICAD. $\mathrm{Na}$ ture 391: 43-50.

Ferri, K.F. and Kroemer, G. 2001. Organelle-specific initiation of cell death pathways. Nat. Cell Biol. 3: E255-E263.

Fesik, S.W. 2000. Insights into programmed cell death through structural biology. Cell 103: 273-282.

Fischer, H., Koenig, U., Eckhart, L., and Tschachler, E. 2002. Human caspase 12 has acquired deleterious mutations. Biochem. Biophys. Res. Commun. 293: 722-726.

Gao, C.F., Ren, S., Zhang, L., Nakajima, T., Ichinose, S., Hara, T., Koike, K., and Tsuchida, N. 2001. Caspase-dependent cytosolic release of cytochrome $c$ and membrane translocation of Bax in p53-induced apoptosis. Exp. Cell Res. 265: 145-151.

Green, D.R. and Reed, J.C. 1998. Mitochondria and apoptosis. Science 281: 1309-1311.

Griffiths, G.J., Dubrez, L., Morgan, C.P., Jones, N.A., Whitehouse, J., Corfe, B.M., Dive, C., and Hickman, J.A. 1999. Cell damage-induced conformational changes of the proapoptotic protein Bak in vivo precede the onset of apoptosis. J. Cell Biol. 144: 903-914. 
Grinberg, M., Sarig, R., Zaltsman, Y., Frumkin, D., Grammatikakis, N., Reuveny, E., and Gross, A. 2002. tBID Homooligomerizes in the mitochondrial membrane to induce apoptosis. J. Biol. Chem. 277: 12237-12245.

Gross, A., McDonnell, J.M., and Korsmeyer, S.J. 1999. Bcl-2 family members and the mitochondria in apoptosis. Genes \& Dev. 13: 1899-1911.

Guo, B., Zhai, D., Cabezas, E., Welsh, K., Nouraini, S., Satterthwait, A.C., and Reed, J.C. 2003. Humanin peptide suppresses apoptosis by interfering with Bax activation. Nature 423: 456-461.

Guo, Y., Srinivasula, S.M., Druilhe, A., Fernandes-Alnemri, T., and Alnemri, E.S. 2002. Caspase-2 induces apoptosis by releasing proapoptotic proteins from mitochondria. J. Biol. Chem. 277: 13430-13437.

Häcki, J., Egger, L., Monney, L., Conus, S., Rossé, T., Fellay, I., and Borner, C. 2000. Apoptotic crosstalk between the endoplasmic reticulum and mitochondria controlled by Bcl-2. Oncogene 19: 2286-2295.

Hakem, R., Hakem, A., Duncan, G.S., Henderson, J.T., Woo, M., Soengas, M.S., Elia, A., de la Pompa, J.L., Kagi, D., Khoo, W., et al. 1998. Differential requirement for caspase 9 in apoptotic pathways in vivo. Cell 94: 339-352.

Hara, H., Takeda, A., Takeuchi, M., Wakeham, A.C., Itie, A., Sasaki, M., Mak, T.W., Yoshimura, A., Nomoto, K., and Yoshida, H. 2002. The apoptotic protease-activating factor 1-mediated pathway of apoptosis is dispensable for negative selection of thymocytes. I. Immunol. 168: 22882295.

Haraguchi, M., Torii, S., Matsuzawa, S., Xie, Z., Kitada, S., Krajewski, S., Yoshida, H., Mak, T.W., and Reed, J.C. 2000. Apoptotic protease activating factor 1 (Apaf-1)-independent cell death suppression by Bcl-2. J. Exp. Med. 191: 1709-1720.

Hausmann, G., O'Reilly, L.A., van Driel, R., Beaumont, J.G., Strasser, A., Adams, J.M., and Huang, D.C.S. 2000. Proapoptotic apoptosis protease-activating Factor 1 (Apaf-1) has a cytoplasmic localization distinct from Bcl-2 or Bcl- $\mathrm{x}_{\mathrm{L}}$. J. Cell Biol. 149: 623-634.

Hawkins, T.E., Das, D., Young, B., and Moss, S.E. 2002. DT40 cells lacking the $\mathrm{Ca}^{2+}$-binding protein annexin 5 are resistant to $\mathrm{Ca}^{2+}$-dependent apoptosis. Proc. Natl. Acad. Sci. 99: 8054-8059.

Hersh, D., Monack, D.M., Smith, M.R., Ghori, N., Falkow, S., and Zychlinsky, A. 1999. The Salmonella invasin SipB induces macrophage apoptosis by binding to caspase-1. Proc. Natl. Acad. Sci. 96: 2396-2401.

Hilbi, H., Moss, J.E., Hersh, D., Chen, Y., Arondel, J., Banerjee, S., Flavell, R.A., Yuan, J., Sansonetti, P.J., and Zychlinsky, A. 1998. Shigella-induced apoptosis is dependent on caspase-1 which binds to IpaB. J. Biol. Chem. 273: 32895-32900.

Hinds, M.G., Lackmann, M., Skea, G.L., Harrison, P.J., Huang, D.C.S., and Day, C.L. 2003. The structure of Bcl-w reveals a role for the C-terminal residues in modulating biological activity. EMBO J. 22: 1497-1507.

Hisahara, S., Yuan, J., Momoi, T., Okano, H., and Miura, M. 2001. Caspase-11 mediates oligodendrocyte cell death and pathogenesis of autoimmune-mediated demyelination. $I$. Exp. Med. 193: 111-122.

Hlaing, T., Guo, R.F., Dilley, K.A., Loussia, J.M., Morrish, T.A., Shi, M.M., Vincenz, C., and Ward, P.A. 2001. Molecular cloning and characterization of DEFCAP-L and -S, two isoforms of a novel member of the mammalian Ced-4 family of apoptosis proteins. J. Biol. Chem. 276: 9230-9238.

Honarpour, N., Du, C., Richardson, J.A., Hammer, R.E., Wang, X., and Herz, J. 2000. Adult Apaf-1-deficient mice exhibit male infertility. Dev. Biol. 218: 248-258.
Honarpour, N., Tabuchi, K., Stark, J.M., Hammer, R.E., Sudhof, T.C., Parada, L.F., Wang, X., Richardson, J.A., and Herz, J. 2001. Embryonic neuronal death due to neurotrophin and neurotransmitter deprivation occurs independent of Apaf-1. Neuroscience 106: 263-274.

Hoppe, J., Kilic, M., Hoppe, V., Sachinidis, A., and Kagerhuber, U. 2002. Formation of caspase-3 complexes and fragmentation of caspase-12 during anisomycin-induced apoptosis in AKR-2B cells without aggregation of Apaf-1. Eur. J. Cell Biol. 81: $567-576$.

Horvitz, H.R. 1999. Genetic control of programmed cell death in the nematode Caenorhabditis elegans. Cancer Res. 59: 1701s-1706s.

Hsu, Y.-T. and Youle, R.J. 1998. Bax in murine thymus is a soluble monomeric protein that displays differential detergent-induced conformations. I. Biol. Chem. 273: 10777-10783.

Hsu, Y.-T., Wolter, K.G., and Youle, R.J. 1997. Cytosol-to-membrane redistribution of $\mathrm{Bax}$ and $\mathrm{Bcl}-\mathrm{X}_{\mathrm{L}}$ during apoptosis. Proc. Natl. Acad. Sci. 94: 3668-3672.

Huang, D.C.S. and Strasser, A. 2000. BH3-only proteins-essential initiators of apoptotic cell death. Cell 103: 839-842.

Janiak, F., Leber, B., and Andrews, D.W. 1994. Assembly of Bcl-2 into microsomal and outer mitochondrial membranes. $I$. Biol. Chem 269: 9842-9849.

Jesenberger, V., Procyk, K.J., Yuan, J., Reipert, S., and Baccarini, M. 2000. Salmonella-induced caspase-2 activation in macrophages: A novel mechanism in pathogen-mediated apoptosis. J. Exp. Med. 192: 1035-1046.

Jimbo, A., Fujita, E., Kouroku, Y., Ohnishi, J., Inohara, N., Kuida, K., Sakamaki, K., Yonehara, S., and Momoi, T. 2003. ER stress induces caspase- 8 activation, stimulating cytochrome $c$ release and caspase-9 activation. Exp. Cell Res. 283: 156-166.

Kang, S.J., Wang, S., Kuida, K., and Yuan, J. 2002. Distinct downstream pathways of caspase-11 in regulating apoptosis and cytokine maturation during septic shock response. Cell Death Differ. 9: 1115-1125.

Kaufman, R.J. 2002. Orchestrating the unfolded protein response in health and disease. J. Clin. Invest. 110: 1389-1398.

Kaufmann, T., Schlipf, S., Sanz, J., Neubert, K., Stein, R., and Borner, C. 2003. Characterization of the signal that directs Bcl- $\mathrm{x}_{\mathrm{L}}$, but not Bcl-2, to the mitochondrial outer membrane. J. Cell Biol. 160: 53-64.

Kawane, K., Fukuyama, H., Yoshida, H., Nagase, H., Ohsawa, Y., Uchiyama, Y., Okada, K., Iida, T., and Nagata, S. 2003. Impaired thymic development in mouse embryos deficient in apoptotic DNA degradation. Nat. Immunol. 4: 138144.

Kerr, J.F.R., Wyllie, A.H., and Currie, A.R. 1972. Apoptosis: A basic biological phenomenon with wide-ranging implications in tissue kinetics. Br. J. Cancer 26: 239-257.

Kilic, M., Schafer, R., Hoppe, J., and Kagerhuber, U. 2002. Formation of noncanonical high molecular weight caspase- 3 and -6 complexes and activation of caspase- 12 during serum starvation induced apoptosis in AKR-2B mouse fibroblasts. Cell Death Differ. 9: 125-137.

Klein, J.A., Longo-Guess, C.M., Rossmann, M.P., Seburn, K.L., Hurd, R.E., Frankel, W.N., Bronson, R.T., and Ackerman, S.L. 2002. The harlequin mouse mutation downregulates apoptosis-inducing factor. Nature 419: 367-374.

Kluck, R.M., Bossy-Wetzel, E., Green, D.R., and Newmeyer, D.D. 1997. The release of cytochrome $c$ from mitochondria-A primary site for Bcl-2 regulation of apoptosis. Science 275: 1132-1136.

Kuida, K., Lippke, J.A., Ku, G., Harding, M.W., Livingston, D.J., 
Su, M.S.-S., and Flavell, R.A. 1995. Altered cytokine export and apoptosis in mice deficient in interleukin-1b converting enzyme. Science 267: 2000-2003.

Kuida, K., Haydar, T.F., Kuan, C.-Y., Gu, Y., Taya, C., Karasuyama, H., Su, M.S.-S., Rakic, P., and Flavell, R.A. 1998. Reduced apoptosis and cytochrome c-mediated caspase activation in mice lacking caspase 9. Cell 94: 325-337.

Kuwana, T., Mackey, M.R., Perkins, G., Ellisman, M.H., Latterich, M., Schneiter, R., Green, D.R., and Newmeyer, D.D. 2002. Bid, Bax, and lipids cooperate to form supramolecular openings in the outer mitochondrial membrane. Cell 111: 331-342.

Lassus, P., Opitz-Araya, X., and Lazebnik, Y. 2002. Requirement for caspase-2 in stress-induced apoptosis before mitochondrial permeabilization. Science 297: 1352-1354.

Letai, A., Bassik, M., Walensky, L., Sorcinelli, M., Weiler, S., and Korsmeyer, S. 2002. Distinct BH3 domains either sensitize or activate mitochondrial apoptosis, serving as prototype cancer therapeutics. Cancer Cell 2: 183-192.

Li, H., Zhu, H., Xu, C.-J., and Yuan, J. 1998. Cleavage of BID by caspase 8 mediates the mitochondrial damage in the Fas pathway of apoptosis. Cell 94: 491-501.

Li, K., Li, Y., Shelton, J.M., Richardson, J.A., Spencer, E., Chen, Z.J., Wang, X., and Williams, R.S. 2000. Cytochrome $c$ deficiency causes embryonic lethality and attenuates stress-induced apoptosis. Cell 101: 389-399.

Li, P., Allen, H., Banerjee, S., Franklin, S., Herzog, L., Johnston, C., McDowell, J., Paskind, M., Rodman, L., Salfeld, J., et al. 1995. Mice deficient in IL-1b-converting enzyme are defective in production of mature IL- $1 \mathrm{~b}$ and resistant to endotoxic shock. Cell 80: 401-411.

Li, P., Nijhawan, D., Budihardjo, I., Srinivasula, S.M., Ahmad, M., Alnemri, E.S., and Wang, X. 1997. Cytochrome c and dATP-dependent formation of Apaf-1/Caspase-9 complex initiates an apoptotic protease cascade. Cell 91: 479489.

Lindsten, T., Ross, A.J., King, A., Zong, W., Rathmell, J.C., Shiels, H.A., Ulrich, E., Waymire, K.G., Mahar, P., Frauwirth, K., et al. 2000. The combined functions of proapoptotic Bcl-2 family members Bak and Bax are essential for normal development of multiple tissues. Mol. Cell 6: 1389-1399.

Liu, X., Dai, S., Zhu, Y., Marrack, P., and Kappler, J.W. 2003. The structure of a Bcl- $\mathrm{x}_{\mathrm{L}} / \mathrm{Bim}$ fragment complex: Implications for Bim function. Immunity (in press).

Luo, X., Budlhardjo, I., Zou, H., Slaughter, C., and Wang, X. 1998. Bid, a Bcl-2 interacting protein, mediates cytochrome $c$ release from mitochondria in response to activation of cell surface death receptors. Cell 94: 481-490.

Marsden, V., O'Connor, L., O'Reilly, L.A., Silke, J., Metcalf, D., Ekert, P., Huang, D.C.S., Cecconi, F., Kuida, K., Tomaselli, K.J., et al. 2002. Apoptosis initiated by Bcl-2-regulated caspase activation independently of the cytochrome $c /$ Apaf1/caspase-9 apoptosome. Nature 419: 634-637.

Martin, S.J. 2002. Destabilizing influences in apoptosis: Sowing the seeds of IAP destruction. Cell 109: 793-796.

Martinon, F., Burns, K., and Tschopp, J. 2002. The inflammasome: A molecular platform triggering activation of inflammatory caspases and processing of proIL-b. Mol. Cell 10: $417-426$.

Martinou, J.-C. and Green, D.R. 2001. Breaking the mitochondrial barrier. Nat. Rev. Mol. Cell Biol. 2: 63-67.

Mikhailov, V., Mikhailova, M., Pulkrabek, D.J., Dong, Z., Venkatachalam, M.A., and Saikumar, P. 2001. Bcl-2 prevents Bax oligomerization in the mitochondrial outer membrane. I. Biol. Chem. 276: 18361-18374.

Mikhailov, V., Mikhailova, M., Degenhardt, K., Venkatacha- lam, M.A., White, E., and Saikumar, P. 2003. Association of Bax and Bak homo-oligomers in mitochondria. Bax requirement for Bak reorganization and cytochrome $c$ release. $J$. Biol. Chem. 278: 5367-5376.

Moriishi, K., Huang, D.C.S., Cory, S., and Adams, J.M. 1999. Bcl-2 family members do not inhibit apoptosis by binding the caspase-activator Apaf-1. Proc. Nat1. Acad. Sci. 96: 9683-9688.

Nakagawa, T. and Yuan, J. 2000. Cross-talk between two cysteine protease families. Activation of caspase-12 by calpain in apoptosis. J. Cell Biol. 150: 887-894.

Nakagawa, T., Zhu, H., Morishima, N., Li, E., Xu, J., Yankner, B.A., and Yuan, J. 2000. Caspase-12 mediates endoplasmicreticulum-specific apoptosis and cytotoxicity by amyloid-b. Nature 403: 98-103.

Nechushtan, A., Smith, C.L., Lamensdorf, I., Yoon, S.H., and Youle, R.J. 2001. Bax and Bak coalesce into novel mitochondria-associated clusters during apoptosis. I. Cell Biol. 153: $1265-1276$.

Newmeyer, D.D. and Ferguson-Miller, S. 2003. Mitochondria: Releasing power for life and unleashing the machineries of death. Cell 112: 481-490.

Newton, K., Harris, A.W., Bath, M.L., Smith, K.G.C., and Strasser, A. 1998. A dominant interfering mutant of FADD/Mort1 enhances deletion of autoreactive thymocytes and inhibits proliferation of mature T lymphocytes. EMBO J. 17: 706-718.

Nijhawan, D., Fang, M., Traer, E., Zhong, Q., Gao, W., Du, F., and Wang, X. 2003. Elimination of Mcl-1 is required for the initiation of apoptosis following ultraviolet irradiation. Genes \& Dev. 17: 1475-1486.

Nomura, M., Shimizu, S., Sugiyama, T., Narita, M., Ito, T., Matsuda, H., and Tsujimoto, Y. 2003. 14-3-3 interacts directly with and negatively regulates proapoptotic Bax. J. Biol. Chem. 278: 2058-2065.

Nutt, L.K., Pataer, A., Pahler, J., Fang, B., Roth, J., McConkey, D.J., and Swisher, S.G. 2002. Bax and Bak promote apoptosis by modulating endoplasmic reticular and mitochondrial $\mathrm{Ca}^{+}$stores. J. Biol. Chem. 277: 9219-9225.

O'Connor, L., Strasser, A., O'Reilly, L.A., Hausmann, G., Adams, J.M., Cory, S., and Huang, D.C.S. 1998. Bim: A novel member of the Bcl-2 family that promotes apoptosis. $E M B O$ J. 17: 384-395.

O'Reilly, L.A., Ekert, P., Harvey, N., Marsden, V., Cullen, L., Vaux, D.L., Hacker, G., Magnusson, C., Pakusch, M., Cecconi, F., et al. 2002. Caspase-2 is not required for thymocyte or neuronal apoptosis even though cleavage of caspase- 2 is dependent on both Apaf-1 and caspase-9. Cell Death Differ. 9: $832-841$.

Okada, H., Suh, W.K., Jin, J., Woo, M., Du, C., Elia, A., Duncan, G.S., Wakeham, A., Itie, A., Lowe, S.W., et al. 2002. Generation and characterization of Smac/DIABLO-deficient mice. Mol. Cell. Biol. 22: 3509-3517.

Paroni, G., Henderson, C., Schneider, C., and Brancolini, C. 2002. Caspase-2 can trigger cytochrome $c$ release and apoptosis from the nucleus. J. Biol. Chem. 277: 1514715161.

Parrish, J., Metters, H., Chen, L., and Xue, D. 2000. Demonstration of the in vivo interaction of key cell death regulators by structure-based design of second-site suppressors. Proc. Natl. Acad. Sci. 97: 11916-11921.

Parrish, J., Li, L., Klotz, K., Ledwich, D., Wang, X., and Xue, D. 2001. Mitochondrial endonuclease $\mathrm{G}$ is important for apoptosis in C. elegans. Nature 412: 90-94.

Penninger, J.M. and Kroemer, G. 2003. Mitochondria, AIF and caspases-Rivaling for cell death execution. Nat. Cell Biol. 5: 97-99. 
Perez, D. and White, E. 2000. TNF-a signals apoptosis through a bid-dependent conformational change in Bax that is inhibited by E1B 19K. Mol. Cell 6: 53-63.

Poyet, J.L., Srinivasula, S.M., Tnani, M., Razmara, M., Fernandes-Alnemri, T., and Alnemri, E.S. 2001. Identification of Ipaf, a human caspase-1-activating protein related to Apaf1. J. Biol. Chem. 276: 28309-28313.

Puthalakath, H. and Strasser, A. 2002. Keeping killers on a tight leash: Transcriptional and posttranslational control of the proapoptotic activity of BH3-only proteins. Cell Death Differ. 9: 505-512.

Puthalakath, H., Huang, D.C.S., O'Reilly, L.A., King, S.M., and Strasser, A. 1999. The proapoptotic activity of the Bcl-2 family member Bim is regulated by interaction with the dynein motor complex. Mol. Cell 3: 287-296.

Puthalakath, H., Villunger, A., O'Reilly, L.A., Beaumont, J.G., Coultas, L., Cheney, R.E., Huang, D.C.S., and Strasser, A. 2001. Bmf: A proapoptotic BH3-only protein regulated by interaction with the myosin $\mathrm{V}$ actin motor complex, activated by anoikis. Science 293: 1829-1832.

Rao, R.V., Castro-Obregon, S., Frankowski, H., Schuler, M., Stoka, V., del Rio, G., Bredesen, D.E., and Ellerby, H.M. 2002. Coupling endoplasmic reticulum stress to the cell death program: An Apaf-1-independent intrinsic pathway. $J$. Biol. Chem. 277: 21836-21842.

Rathmell, J.C., Lindsten, T., Zong, W.-X., Cinalli, R.M., and Thompson, C.B. 2002. Deficiency in Bak and Bax perturbs thymic selection and lymphoid homeostasis. Nat. Immunol. 3: 932-939.

Read, S.H., Baliga, B.C., Ekert, P.G., Vaux, D.L., and Kumar, S. 2002. A novel Apaf-1-independent putative caspase-2 activation complex. J. Cell Biol. 159: 739-745.

Robertson, J.D., Enoksson, M., Suomela, M., Zhivotovsky, B., and Orrenius, S. 2002. Caspase-2 acts upstream of mitochondria to promote cytochrome $c$ release during etoposide-induced apoptosis. J. Biol. Chem. 277: 29803-29809.

Rodriguez, J. and Lazebnik, Y. 1999. Caspase-9 and APAF-1 form an active holoenzyme. Genes \& Dev. 13: 3179-3184.

Roucou, X., Montessuit, S., Antonsson, B., and Martinou, J.C. 2002. Bax oligomerization in mitochondrial membranes requires tBid (caspase-8-cleaved Bid) and a mitochondrial protein. Biochem. J. 368: 915-921.

Rowe, S.J., Allen, L., Ridger, V.C., Hellewell, P.G., and Whyte, M.K.B. 2002. Caspase-1 deficient mice have delayed neutrophil apoptosis and a prolonged inflammatory response to lipopolysaccharide-induced acute lung injury. I. Immunol. 169: 6401-6407.

Rudner, J., Lepple-Wienhues, A., Budach, W., Berschauer, J., Friedrich, B., Wesselborg, S., Schulze-Osthoff, K., and Belka, C. 2001. Wild-type, mitochondrial and ER-restricted Bcl-2 inhibit DNA damage-induced apoptosis but do not affect death receptor-induced apoptosis. J. Cell Sci. 114: 4161-4172.

Ruffolo, S.C. and Shore, G.C. 2003. BCL-2 selectively interacts with the BID-induced open conformer of BAK, inhibiting BAK auto-oligomerization. J. Biol. Chem. 278: 25039-25045.

Saito, M., Korsmeyer, S.J., and Schlesinger, P.H. 2000. BAXdependent transport of cytochrome $\mathrm{c}$ reconstituted in pure liposomes. Nat. Cell Biol. 2: 553-555.

Salmena, L., Lemmers, B., Hakem, A., Matysiak-Zablocki, E., Murakami, K., Au, B., Berry, D.M., Tamblyn, L., Shehabeldin, E.M., Migon, E., et al. 2003. Essential role for caspase 8 in T-cell homeostasis and T-cell-mediated immunity. Genes \& Dev. 17: 883-895.

Samejima, K., Tone, S., and Earnshaw, W.C. 2001. CAD/DFF40 nuclease is dispensable for high molecular weight DNA cleavage and stage I chromatin condensation in apoptosis. I. Biol. Chem. 276: 45427-45432.

Sattler, M., Liang, H., Nettesheim, D., Meadows, R.P., Harlan, J.E., Eberstadt, M., Yoon, H.S., Shuker, S.B., Chang, B.S., Minn, A.J., et al. 1997. Structure of Bcl- $\mathrm{x}_{\mathrm{L}}-\mathrm{Bak}$ peptide complex: Recognition between regulators of apoptosis. Science 275: 983-986.

Sawada, M., Hayes, P., and Matsuyama, S. 2003. Cytoprotective membrane-permeable peptides designed from the Bax-binding domain of Ku70. Nat. Cell Biol. 5: 352-357.

Scorrano, L., Oakes, S.A., Opferman, J.T., Cheng, E.H., Sorcinelli, M.D., Pozzan, T., and Korsmeyer, S.J. 2003. BAX and BAK regulation of endoplasmic reticulum $\mathrm{Ca}^{2+}$ : A control point for apoptosis. Science 300: 135-139.

Shearwin-Whyatt, L.M., Harvey, N.L., and Kumar, S. 2000. Subcellular localization and CARD-dependent oligomerization of the death adaptor RAIDD. Cell Death Differ. 7: 155-165.

Shi, Y. 2002. Mechanisms of caspase activation and inhibition during apoptosis. Mol. Cell 9: 459-470.

Srinivasula, S.M., Poyet, J.L., Razmara, M., Datta, P., Zhang, Z., and Alnemri, E.S. 2002. The PYRIN-CARD protein ASC is an activating adaptor for caspase-1. J. Biol. Chem. 277: 21119-21122.

Strasser, A., Harris, A.W., Huang, D.C.S., Krammer, P.H., and Cory, S. 1995. Bcl-2 and Fas/APO-1 regulate distinct pathways to lymphocyte apoptosis. EMBO J. 14: 61366147.

Strasser, A., O'Connor, L., and Dixit, V.M. 2000. Apoptosis signaling. Annu. Rev. Biochem. 69: 217-245.

Suzuki, M., Youle, R.J., and Tjandra, N. 2000. Structure of Bax: Coregulation of dimer formation and intracellular localization. Cell 103: 645-654.

Thomenius, M.J., Wang, N.S., Reineks, E.Z., Wang, Z., and Distelhorst, C.W. 2003. Bcl-2 on the endoplasmic reticulum regulates Bax activity by binding to $\mathrm{BH} 3$ only proteins. $J$. Biol. Chem. 278: 6243-6250.

Thornberry, N.A. and Lazebnik, Y. 1998. Caspases: Enemies within. Science 281: 1312-1316.

Van de Craen, M., Declercq, W., Van den brande, I., Fiers, W., and Vandenabeele, P. 1999. The proteolytic procaspase activation network: An in vitro analysis. Cell Death Differ. 6: 1117-1124.

van Loo, G., Saelens, X., Matthijssens, F., Schotte, P., Beyaert, R., Declercq, W., and Vandenabeele, P. 2002. Caspases are not localized in mitochondria during life or death. Cell Death Differ. 9: 1207-1211.

Varfolomeev, E.E., Schuchmann, M., Luria, V., Chiannilkulchai, N., Beckmann, J.S., Mett, I.L., Rebrikov, D., Brodianski, V.M., Kemper, O.C., Kollet, O., et al. 1998. Targeted disruption of the mouse Caspase 8 gene ablates cell death induction by the TNF receptors, Fas/Apo1, and DR3 and is lethal prenatally. Immunity 9: 267-276.

Vaux, D.L., Cory, S., and Adams, J.M. 1988. Bcl-2 gene promotes haemopoietic cell survival and cooperates with c-myc to immortalize pre-B cells. Nature 335: 440-442.

Vaux, D.L., Weissman, I.L., and Kim, S.K. 1992. Prevention of programmed cell death in Caenorhabditis elegans by human bcl-2. Science 258: 1955-1957.

Verhagen, A.M., Ekert, P.G., Pakusch, M., Silke, J., Connolly, L.M., Reid, G.E., Moritz, R.L., Simpson, R.J., and Vaux, D.L. 2000. Identification of DIABLO, a mammalian protein that promotes apoptosis by binding to and antagonizing inhibitor of apoptosis (IAP) proteins. Cell 102: 43-53.

Wang, X. 2001. The expanding role of mitochondria in apoptosis. Genes \& Dev. 15: 2922-2933.

Wang, X., Yang, C., Chai, J., Shi, Y., and Xue, D. 2002. Mecha- 
nisms of AIF-mediated apoptotic DNA degradation in Caenorhabditis elegans. Science 298: 1587-1592.

Wei, M.C., Lindsten, T., Mootha, V.K., Weiler, S., Gross, A., Ashiya, M., Thompson, C.B., and Korsmeyer, S.J. 2000. tBID, a membrane-targeted death ligand, oligomerizes BAK to release cytochrome c. Genes \& Dev. 14: 2060-2071.

Wei, M.C., Zong, W.X., Cheng, E.H., Lindsten, T., Panoutsakopoulou, V., Ross, A.J., Roth, K.A., MacGregor, G.R., Thompson, C.B., and Korsmeyer, S.J. 2001. Proapoptotic BAX and BAK: A requisite gateway to mitochondrial dysfunction and death. Science 292: 727-730.

Wilson-Annan, J., O’Reilly, L.A., Crawford, S.A., Hausmann, G., Beaumont, J.G., Parma, L.P., Lackmann, M., Hinds, M.G., Day, C.L., Adams, J.M., et al. 2003. Proapoptotic BH3only proteins trigger tight membrane association and neutralize prosurvival Bcl-w. J. Cell Biol. (in press).

Xue, D. and Horvitz, H.R. 1997. Caenorhabditis elegans Ced-9 protein is a bifunctional cell-death inhibitor. Nature 390: 305-308.

Yamaguchi, H., Bhalla, K., and Wang, H.G. 2003. Bax plays a pivotal role in thapsigargin-induced apoptosis of human colon cancer HCT116 cells by controlling Smac/Diablo and Omi/HtrA2 release from mitochondria. Cancer Res. 63: 1483-1489.

Yin, X.-M., Wang, K., Gross, A., Zhao, Y., Zinkel, S., Klocke, B., Roth, K.A., and Korsmeyer, S.J. 1999. Bid-deficient mice are resistant to Fas-induced hepatocellular apoptosis. Nature 400: 886-891.

Yoneda, T., Imaizumi, K., Oono, K., Yui, D., Gomi, F., Katayama, T., and Tohyama, M. 2001. Activation of caspase-12, an endoplastic reticulum (ER) resident caspase, through tumor necrosis factor receptor-associated factor 2-dependent mechanism in response to the ER stress. J. Biol. Chem. 276: $13935-13940$.

Yoshida, H., Kong, Y.-Y., Yoshida, R., Elia, A.J., Hakem, A., Hakem, R., Penninger, J.M., and Mak, T.W. 1998. Apaf1 is required for mitochondrial pathways of apoptosis and brain development. Cell 94: 739-750.

Yu, J., Wang, Z., Kinzler, K.W., Vogelstein, B., and Zhang, L. 2003. PUMA mediates the apoptotic response to p53 in colorectal cancer cells. Proc. Natl. Acad. Sci. 100: 1931-1936.

Zha, J., Weiler, S., Oh, K.J., Wei, M.C., and Korsmeyer, S.J. 2000. Posttranslational N-myristoylation of BID as a molecular switch for targeting mitochondria and apoptosis. Science 290: 1761-1765.

Zimmermann, K.C., Ricci, J.E., Droin, N.M., and Green, D.R. 2002. The role of ARK in stress-induced apoptosis in Drosophila cells. J. Cell Biol. 156: 1077-1087.

Zong, W.X., Lindsten, T., Ross, A.J., MacGregor, G.R., and Thompson, C.B. 2001. BH3-only proteins that bind prosurvival Bcl-2 family members fail to induce apoptosis in the absence of Bax and Bak. Genes \& Dev. 15: 1481-1486.

Zong, W.X., Li, C., Hatzuvassiliou, G., Lindsten, T., Yu, Q.C., Yuan, J., and Thompson, C.B. 2003. Bax and Bak can localize to the endoplasmic reticulum to initiate apoptosis. I. Cell Biol. 162: 59-69. 


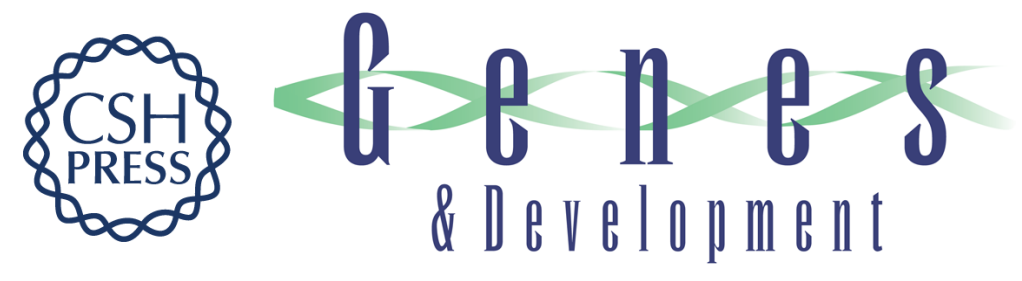

\section{Ways of dying: multiple pathways to apoptosis}

Jerry M. Adams

Genes Dev. 2003, 17:

Access the most recent version at doi:10.1101/gad.1126903

References This article cites 148 articles, 79 of which can be accessed free at: http://genesdev.cshlp.org/content/17/20/2481.full.html\#ref-list-1

License

Email Alerting Receive free email alerts when new articles cite this article - sign up in the box at the top Service right corner of the article or click here.

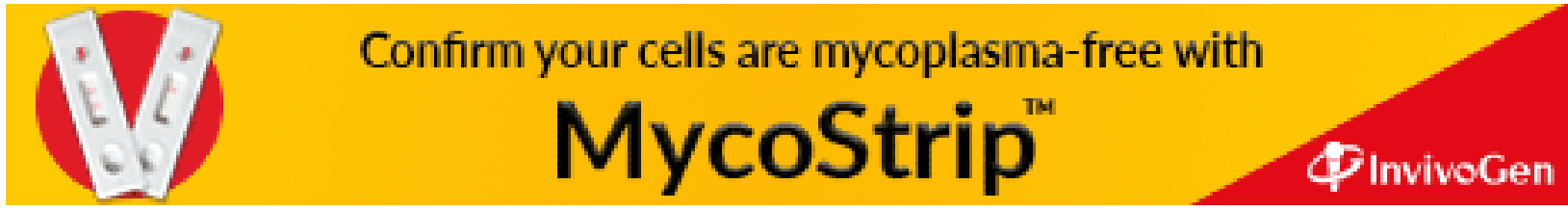

